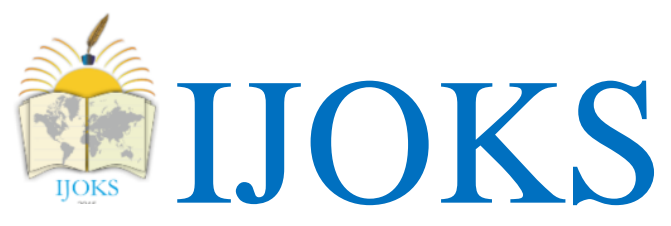

International Journal of Kurdish Studies

(ISSN:2149-2751)

5 (1), pp. $103-120$

http://www.ijoks.com

\title{
Detailed analysis of text: An example of the text of the poet Kazal Ahmed
}

\section{Ala Dara Abdul Majid ${ }^{1}$}

Received: May 04, 2018 Reviewed: Nov 07, 2018 Accepted: Nov 10, 2018

\begin{abstract}
The subject of the study is a detailed analysis of text; in general the analysis of literary texts and giving accurate examples of such poetic texts in a way that internally and externally shows the author's skills, ideas and knowledge.

The study consists of two parts. The first part deals with two topics, which are the definition of text analysis and its relation to literary criticism and how to understand literary texts and its relation to text construction. The second part also contains two topics, which are an explanation of accurate analysis with an example poetic text and its analysis.
\end{abstract}

The reason for choosing this poetic text which belongs to the poet "Kazal Ahmed" is the peculiarity of the text and its content of different themes. The researcher has tried to analyze the internal and external aspects of the text.

Key words: Detailed, Text analysis, Literary theory, Kurdish poem

\section{Recommended citation:}

Abdul Majid, A. D., (2019). Detailed analysis of text: An example of the text of the poet Kazal Ahmed. International Journal of Kurdish Studies 5 (1), 103 - 120 DOI: 10.21600/ijoks.516492

$$
\text { بوخته: }
$$

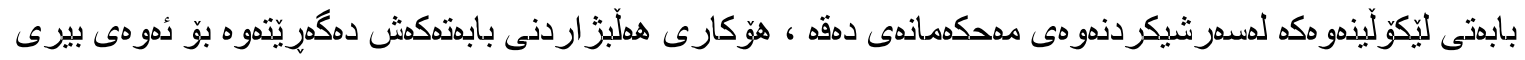

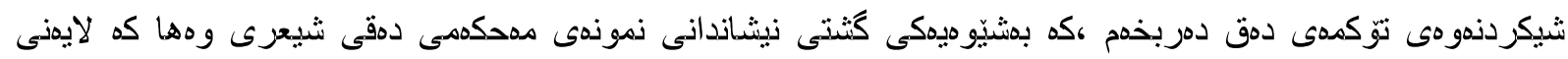

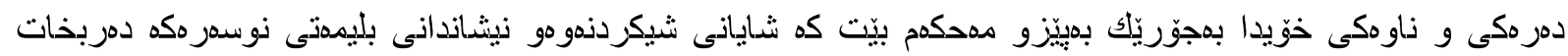

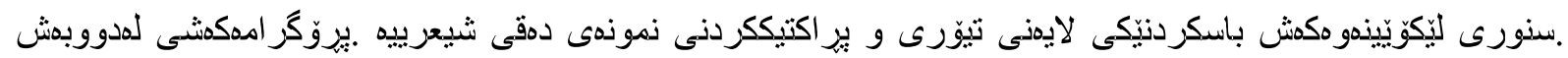

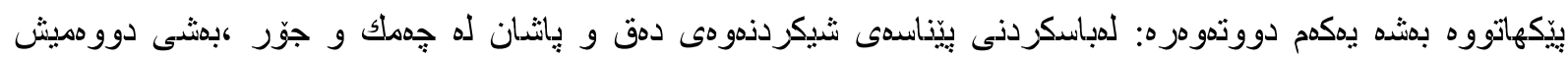

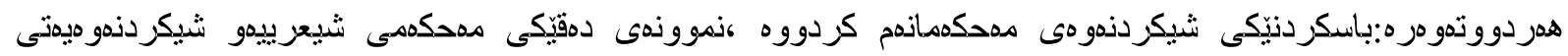

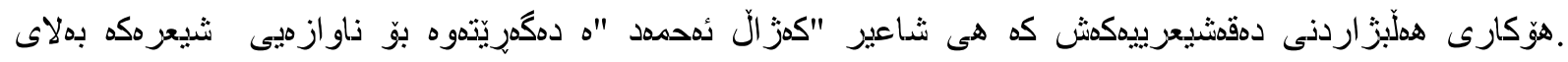

\footnotetext{
${ }^{1}$ Assistant lecturer, Department of Kurdish language, Faculty of education, Koya University, E-mail; ala.dara@koyauniversity.org, ORCID NO: https://orcid.org/0000-0001-6777-0112
} 


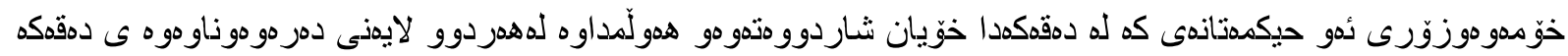
لَّيكداذهو مدى بوّ بكمم . كليله وشهكان :شيكردذهو هى مهحكمى دمق ، تيوّرى ئددمبى ، كمز الّ ئهمهد ،شيعزى كوردى . سدرجهاو مكان:

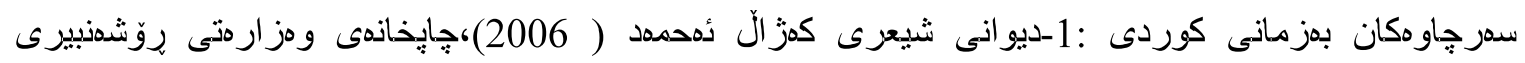

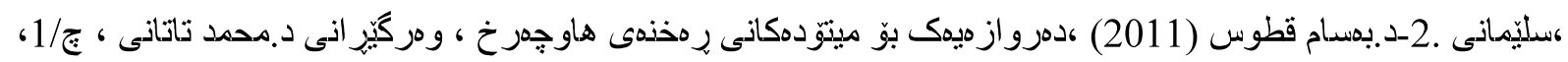

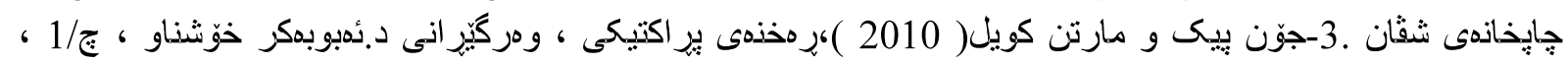

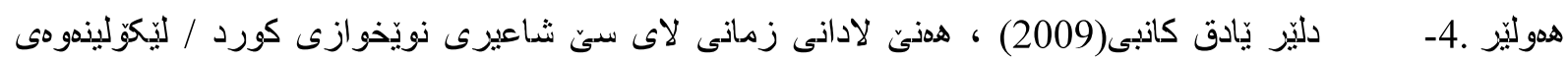

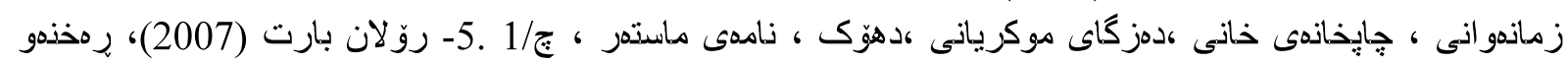

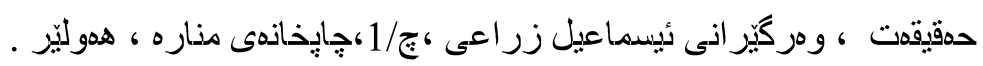

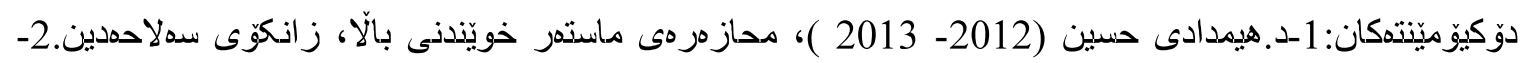

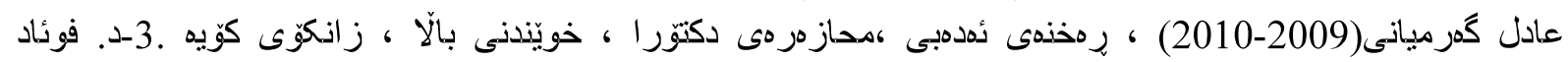

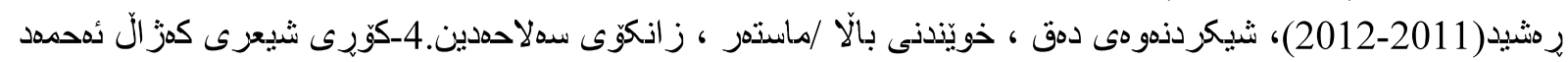
(1995) كوّيه.

سهرجاوهكان بهزمانى عهر دبى:1-هندرى ويسينجز(2001)، قوة النقد البناء، عبد الكريم العقيل ؟،هكتبة الجريز

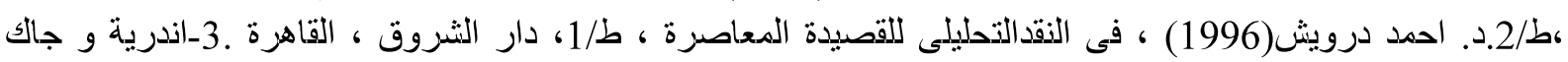

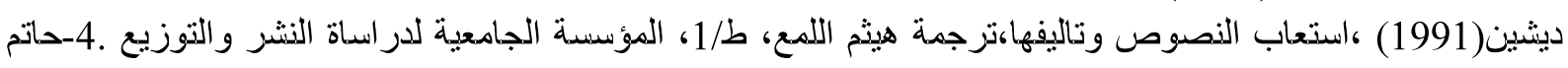

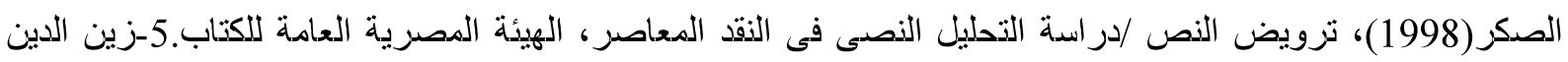

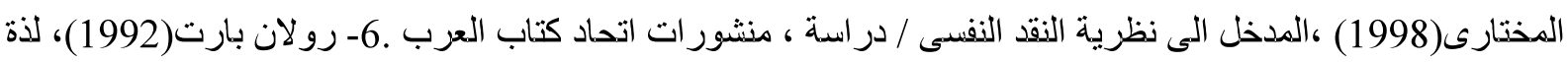

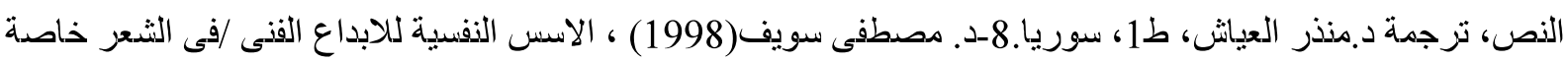

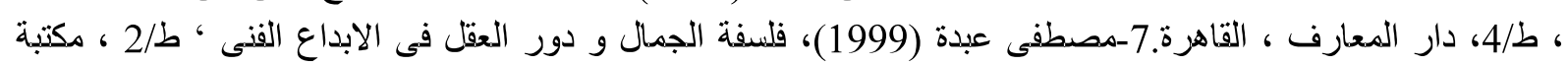

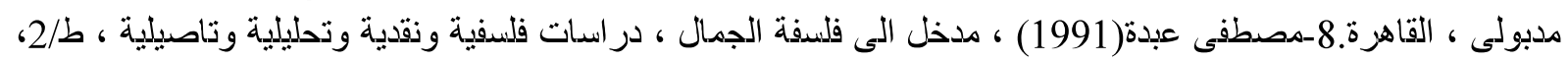

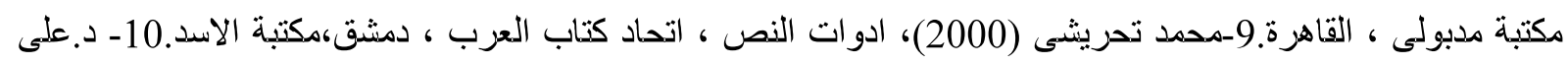

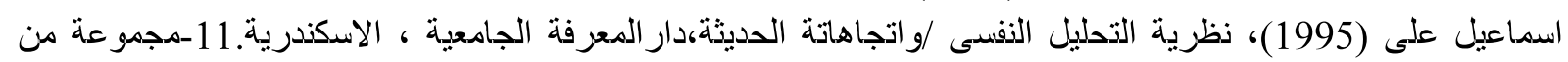

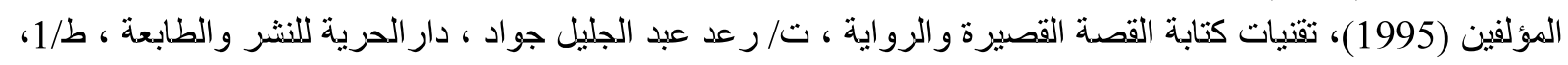

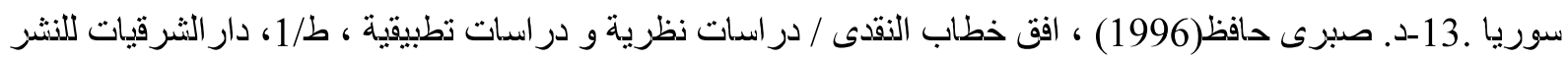
و التوزيع ، القاهرة.

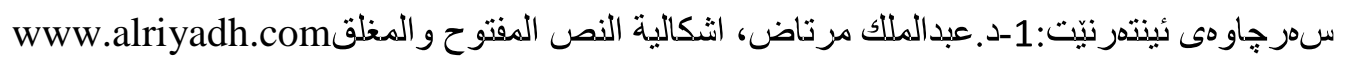

بمثشى يمكمم :

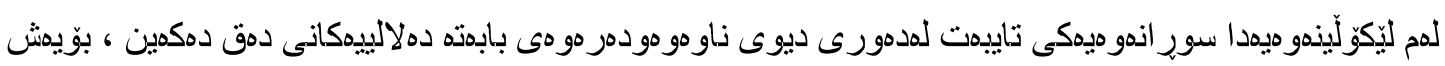

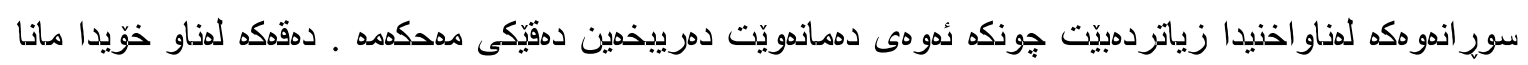

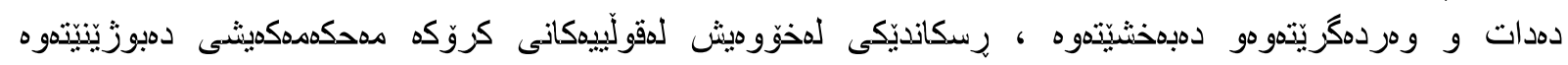

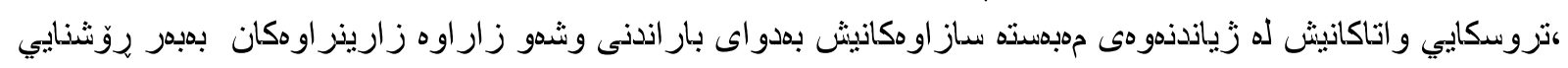

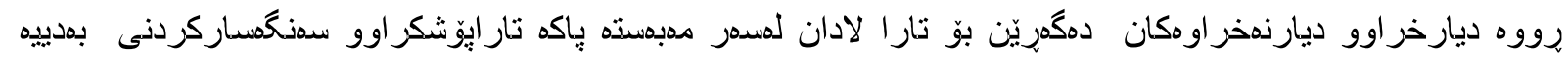

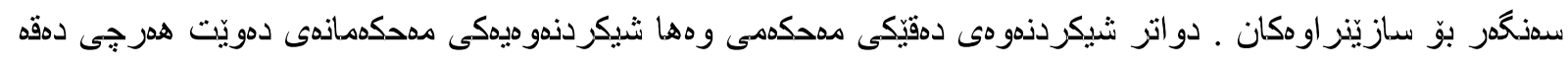

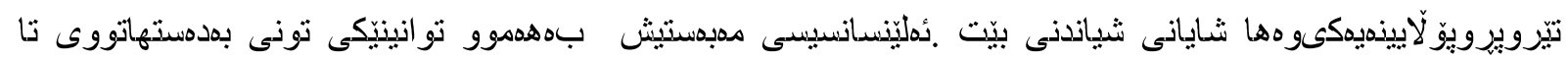

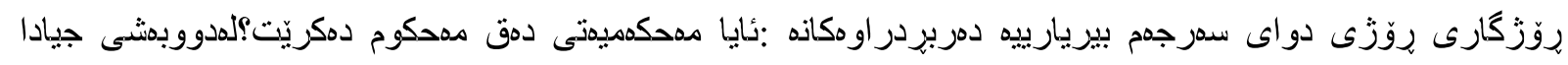

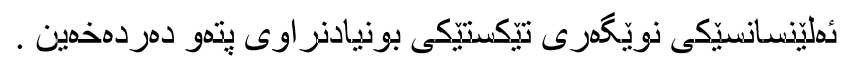

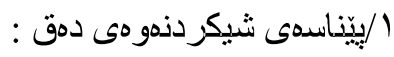




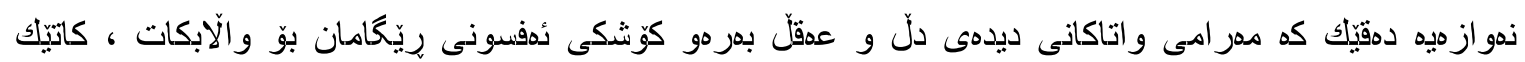

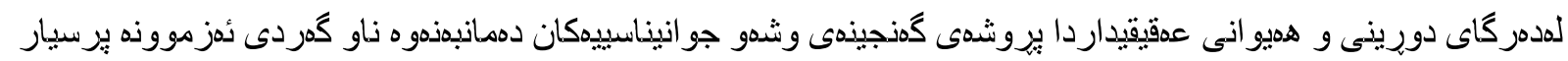

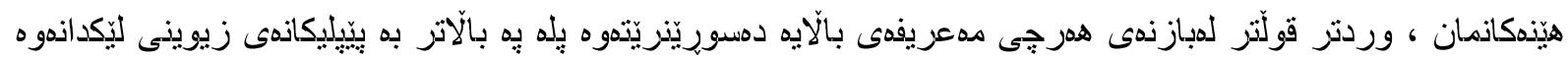

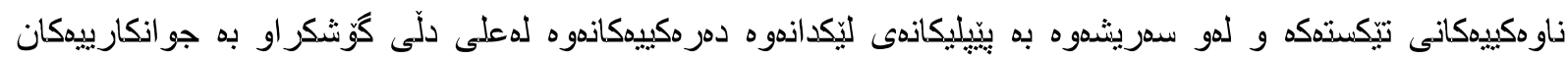

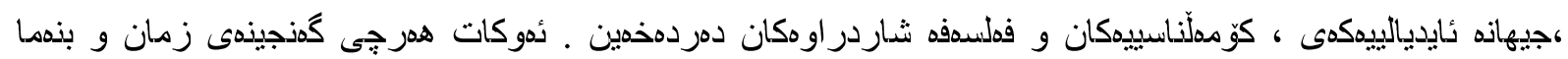

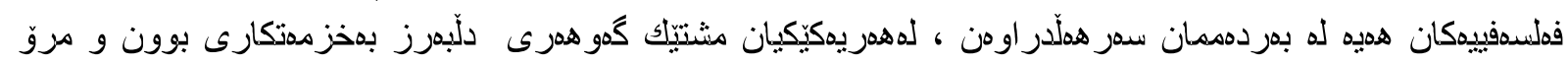

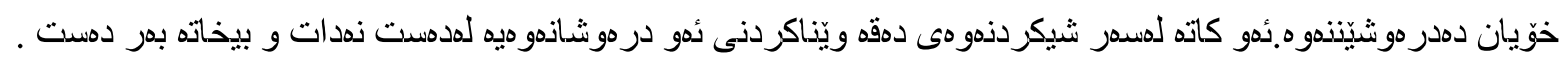
شيكردنهو (Text analyisis)

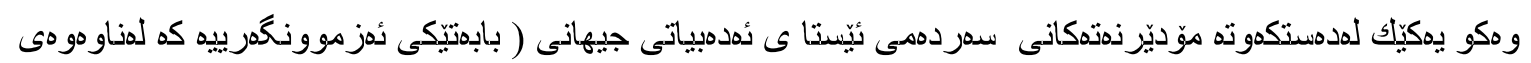

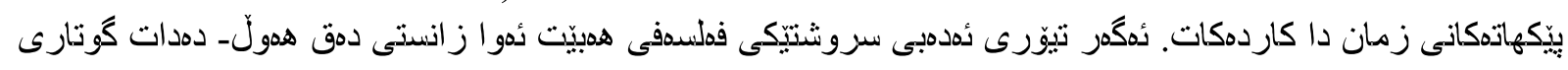

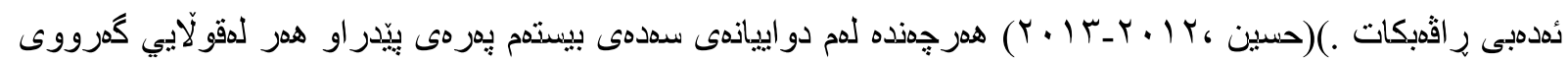

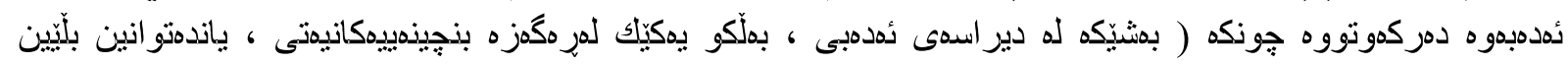

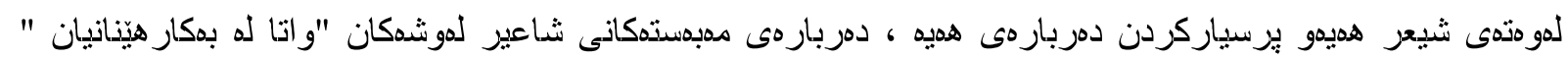

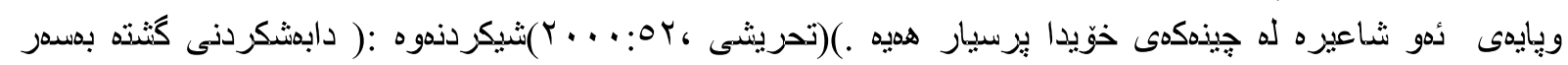

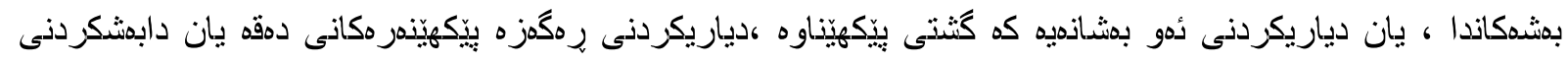

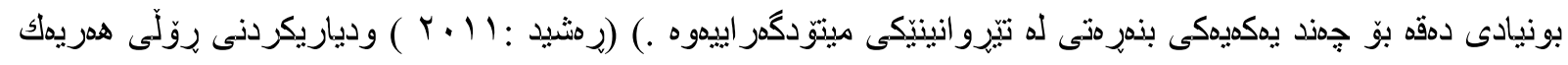

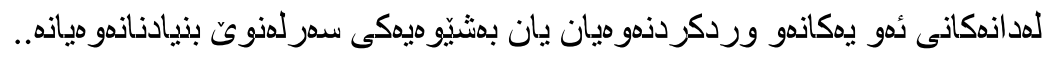
/ /جهمكى شيكردذهوه :

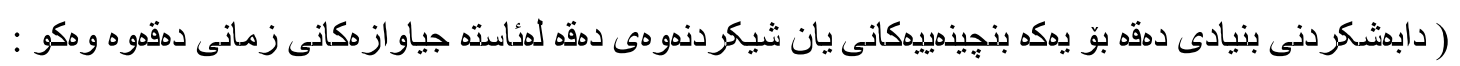

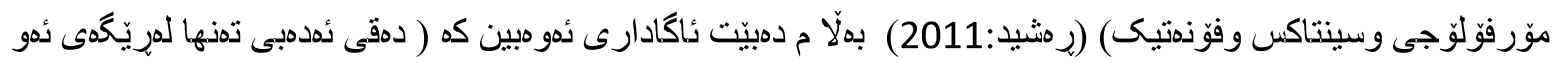

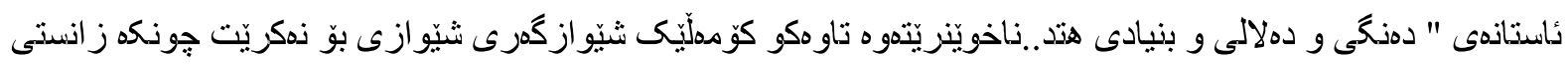

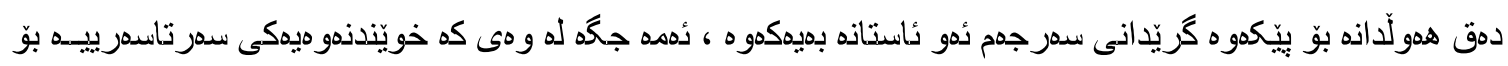

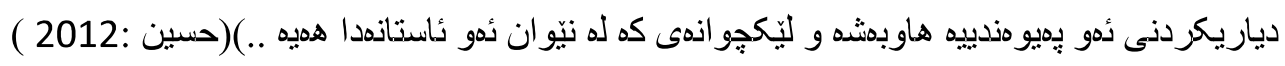

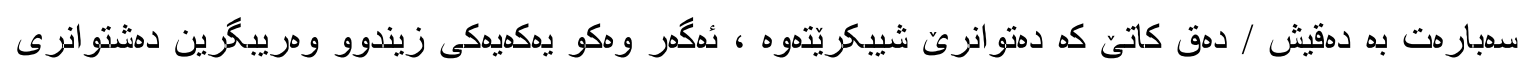

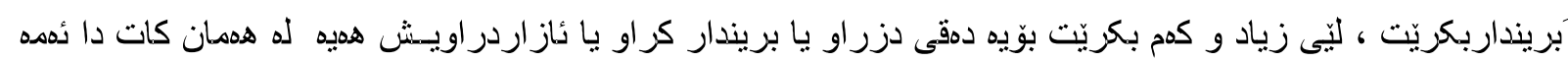

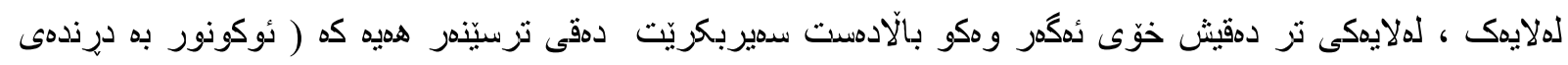

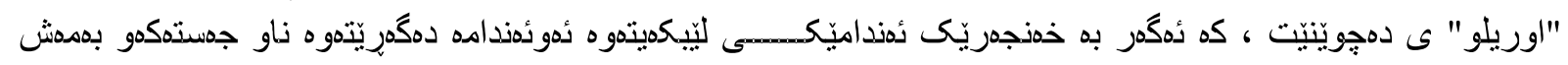

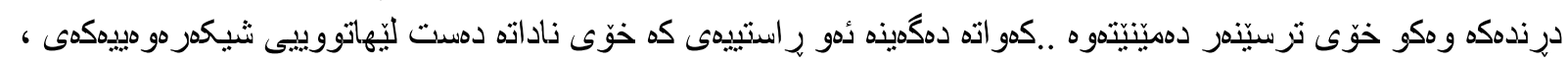

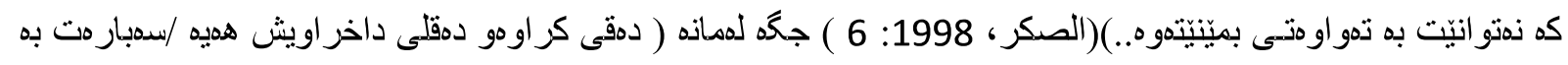

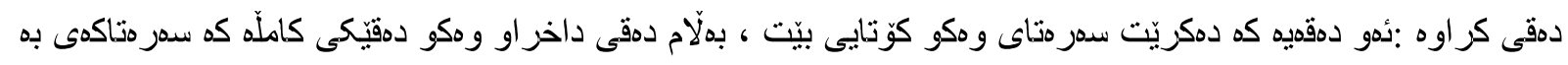

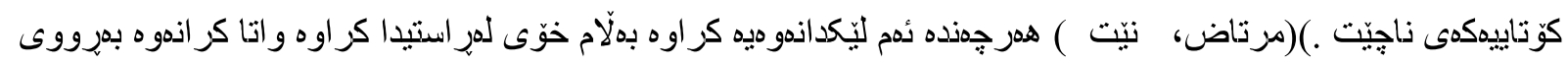

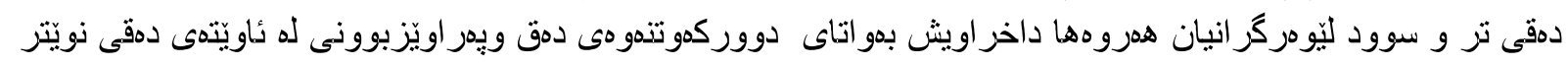

لـخوّى.

-3دهركموتنى ميّزوويى شيكر دذهوهى دمق/" جياو ازى له كلتوورى عهر هبى و روّزَّناو ايى:"

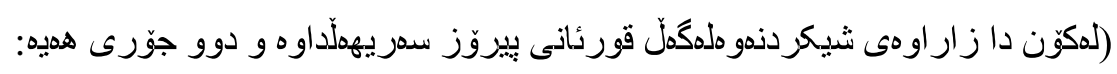




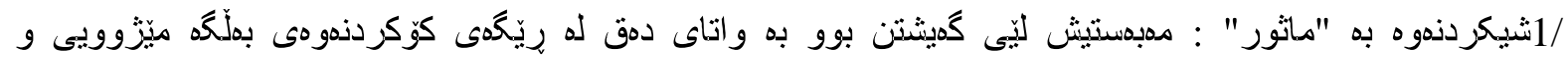

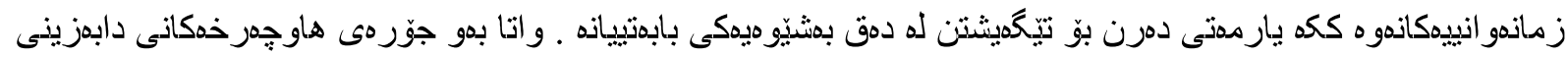

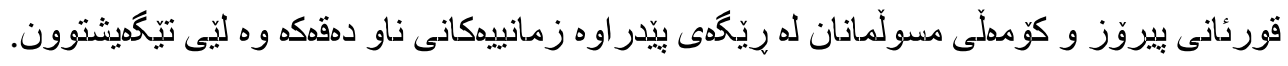

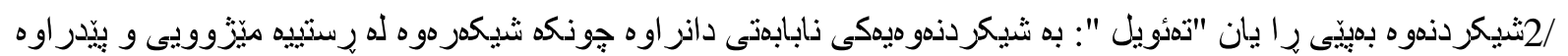

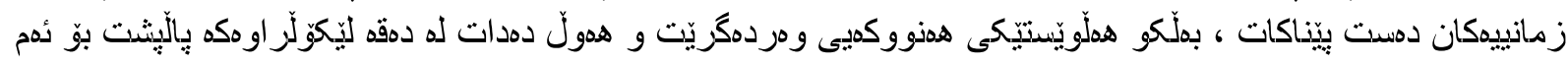

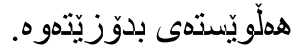

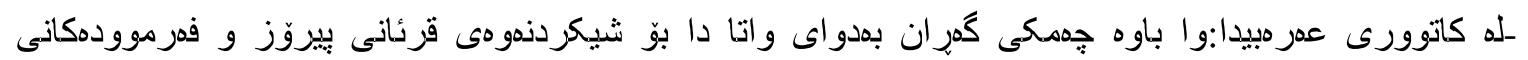

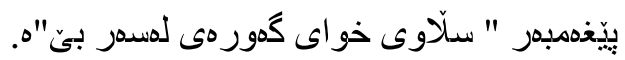

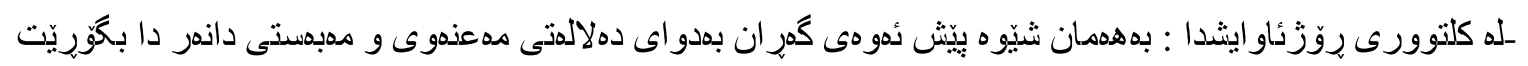

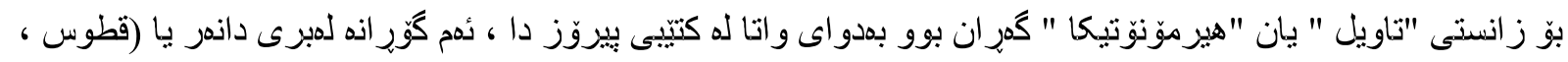

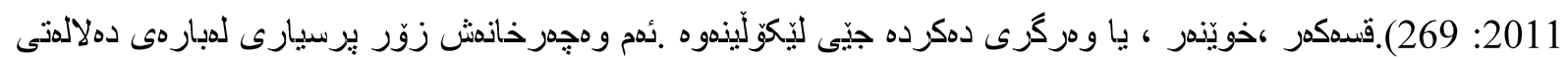

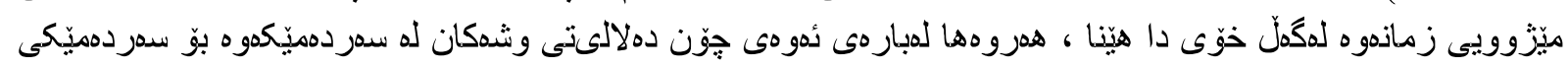

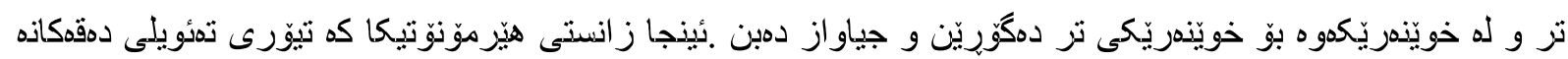

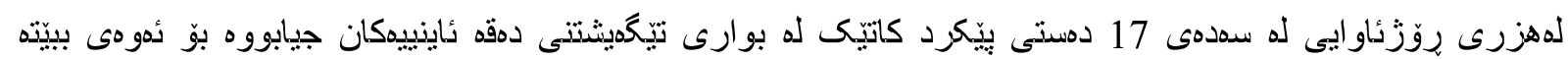

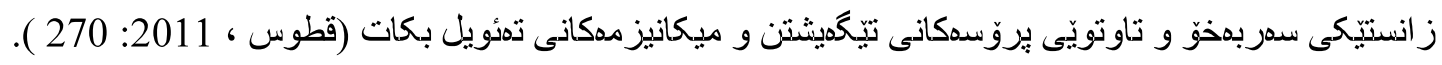

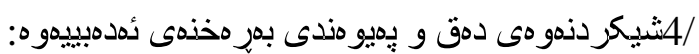

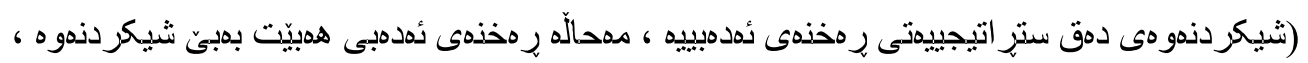

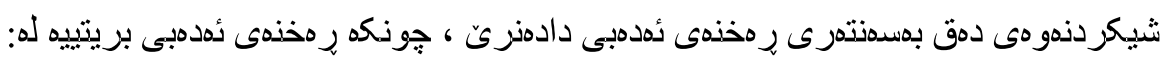

شيكردنهوه

$$
\downarrow
$$
بِوَلينكردن

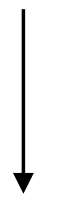

دهربزينى حوكميّكى رِ مخنهييه بهسهر دهقكهدا.

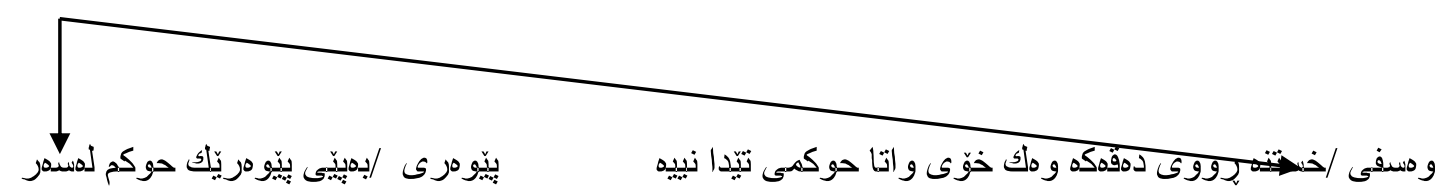

دمقهكددا دهدات .

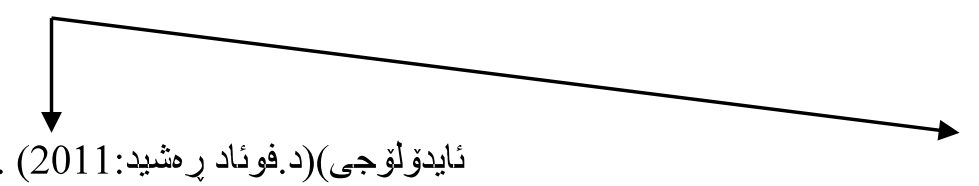

ثئيتاتيكى

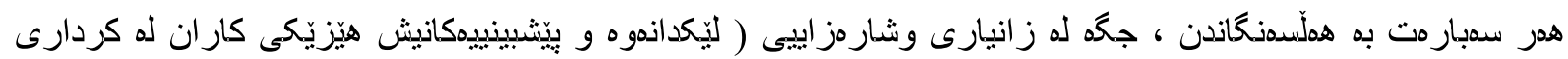

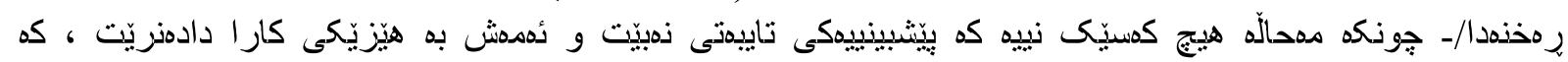

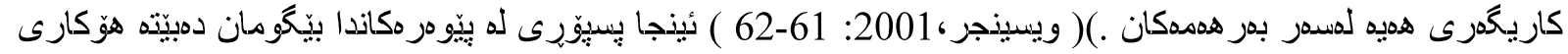

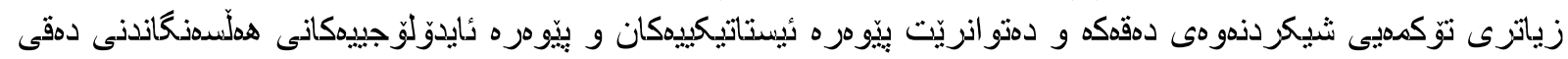

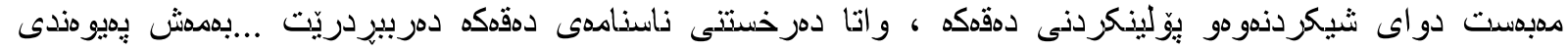

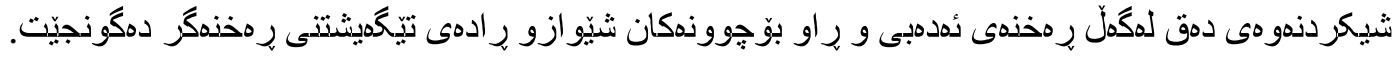




$$
\begin{aligned}
& \text { )/4ائاستهانى شيكردندو مى دمق: } \\
& \text {-1ئاستى دهذكى. } \\
& \text {-2ئاستى بيّكهاتديى. } \\
& \text {-3ئاستى (دهلالى) و اتايى. } \\
& \text {-4ئاستى دئقاعى (موّسيقى ). }
\end{aligned}
$$

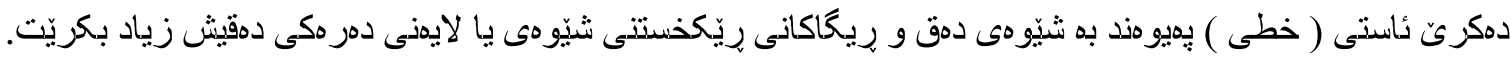
لَيّر هوه شيكر دذهو مى دمر مكى بوّ دمق ديّته ئار اوه ،

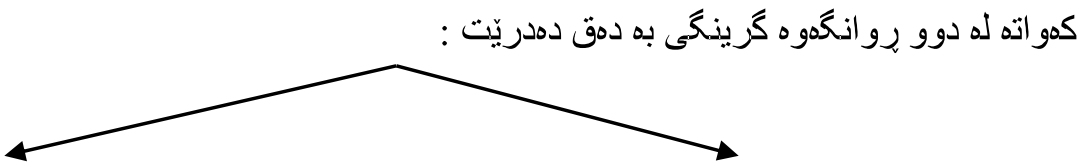

ناوهكى / 1-ـدموهى له دمرهوهى دمق كؤدمبيّتهوه .

دةرةكى /دمكذِيَّريّتهوه بوّ :

$$
2
$$

1 - 1 ميّزوو

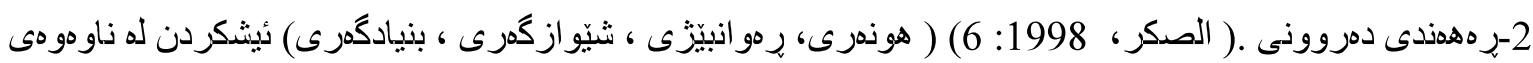

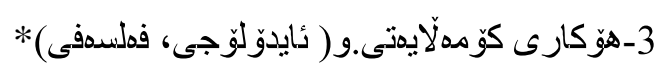

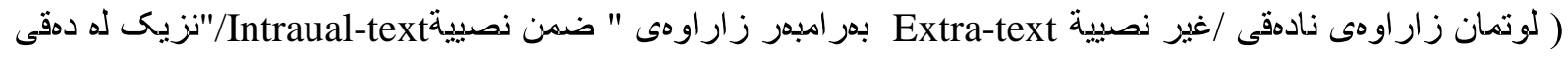

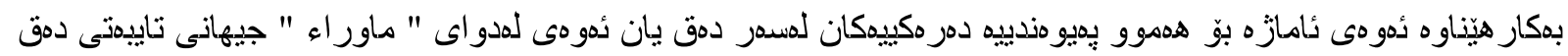

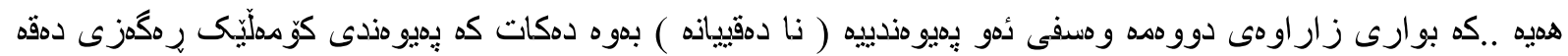

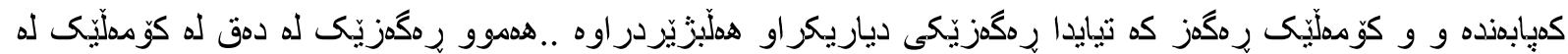

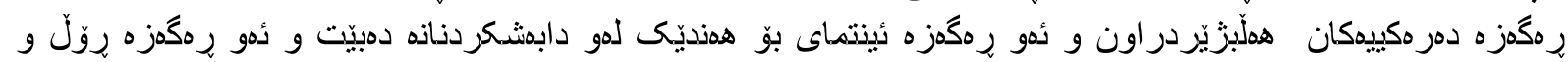

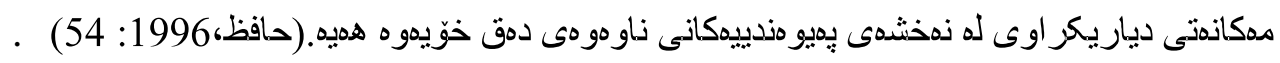

$$
\begin{aligned}
& 5 \text { - هوَّيدكانى بِديدابوونى شيكردذهو مى دمق: }
\end{aligned}
$$

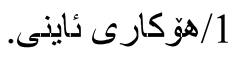

$$
\begin{aligned}
& \text { 2/هو كارى بو ار هكانى زانست. } \\
& \text { 3/زورى بهر همدى شيعز . }
\end{aligned}
$$

4/معجم سدرجهاو مو زار اوهكان . بهتاييهت بوّ زمانى عهر مبى).

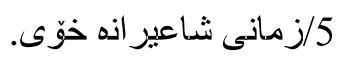

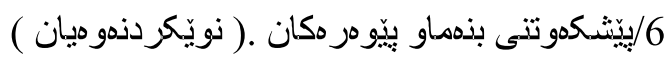

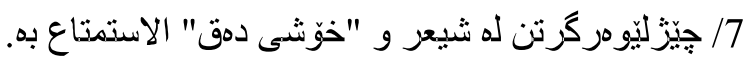




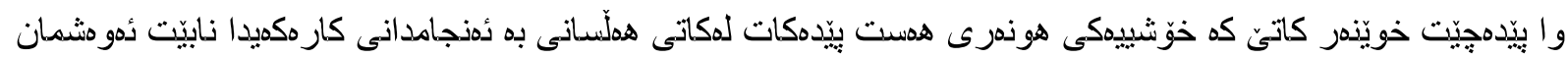

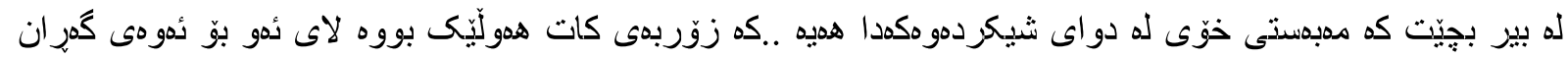

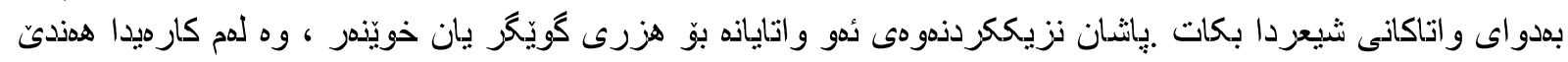

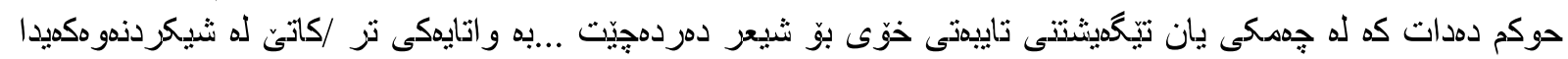

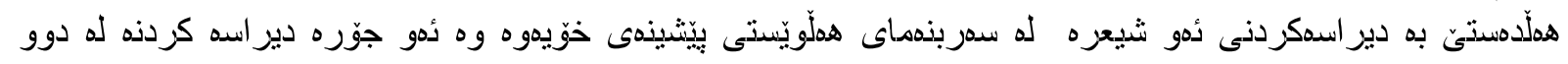

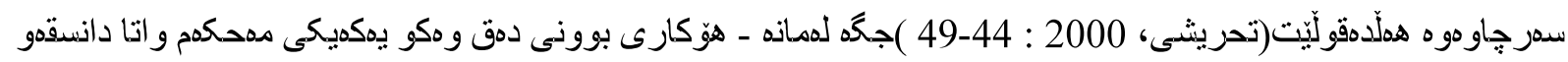
كار امديى دارشتنى.

ـ خويّدندوهى نويَ ى خويّنهر بوّ دمق :

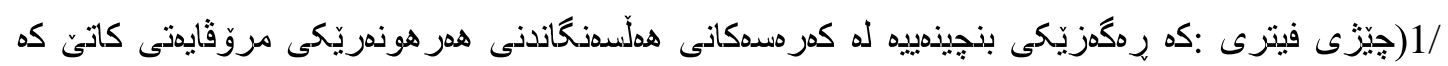

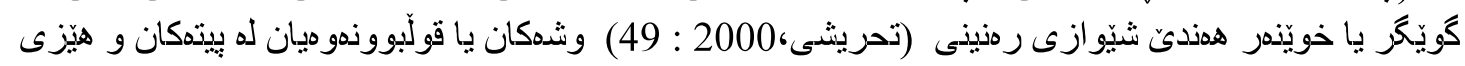

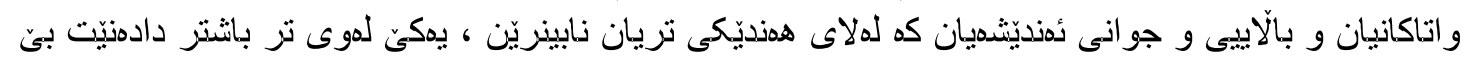

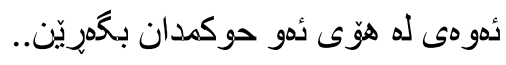

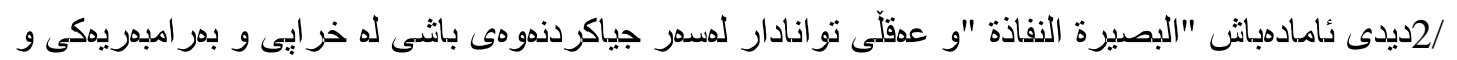

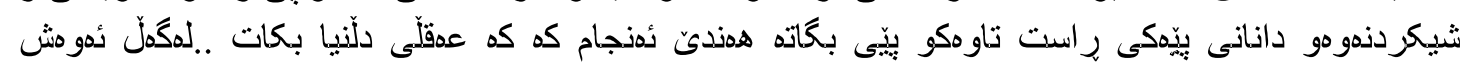

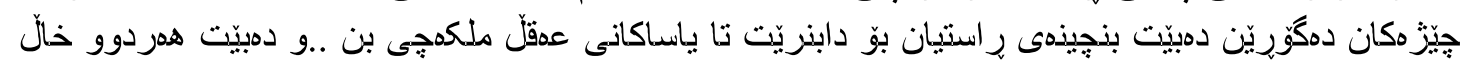

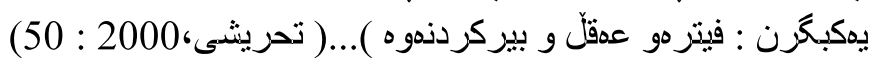

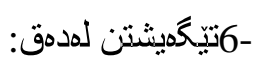

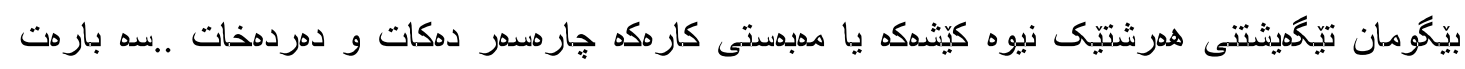

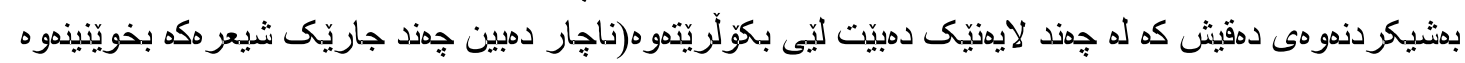

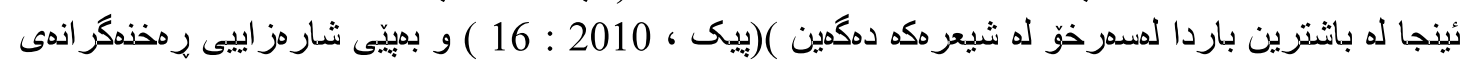

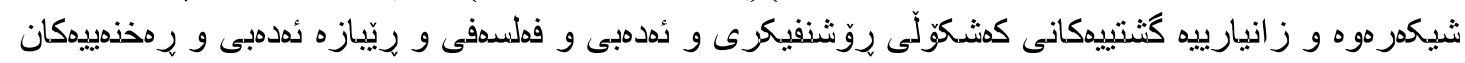

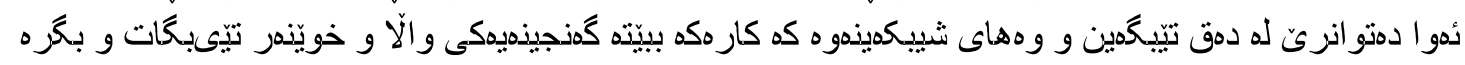

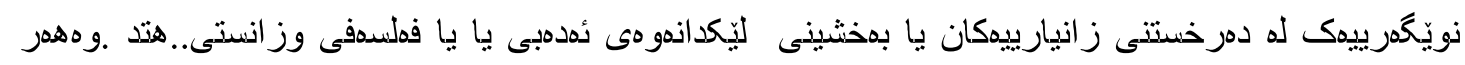

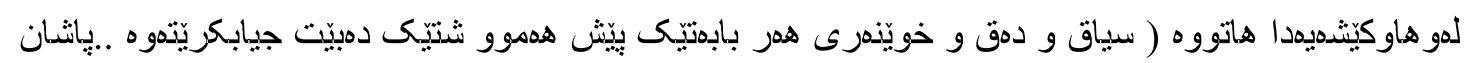

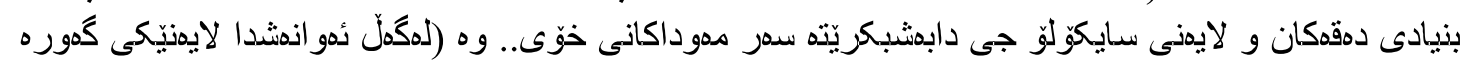

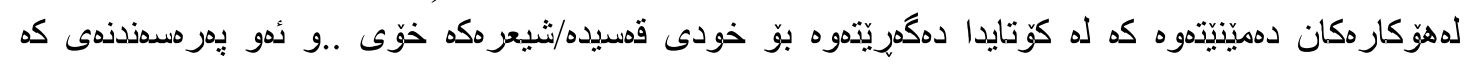

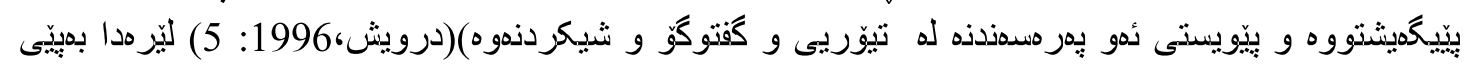

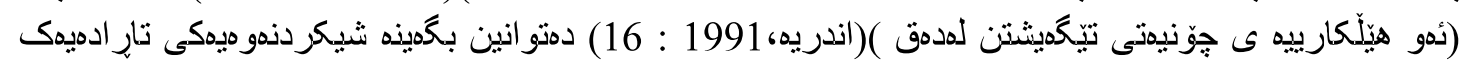

تندو او :

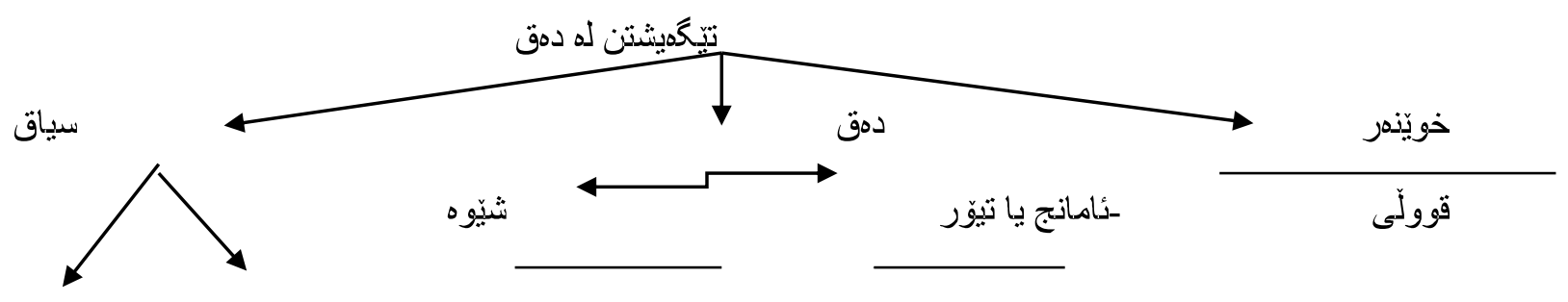




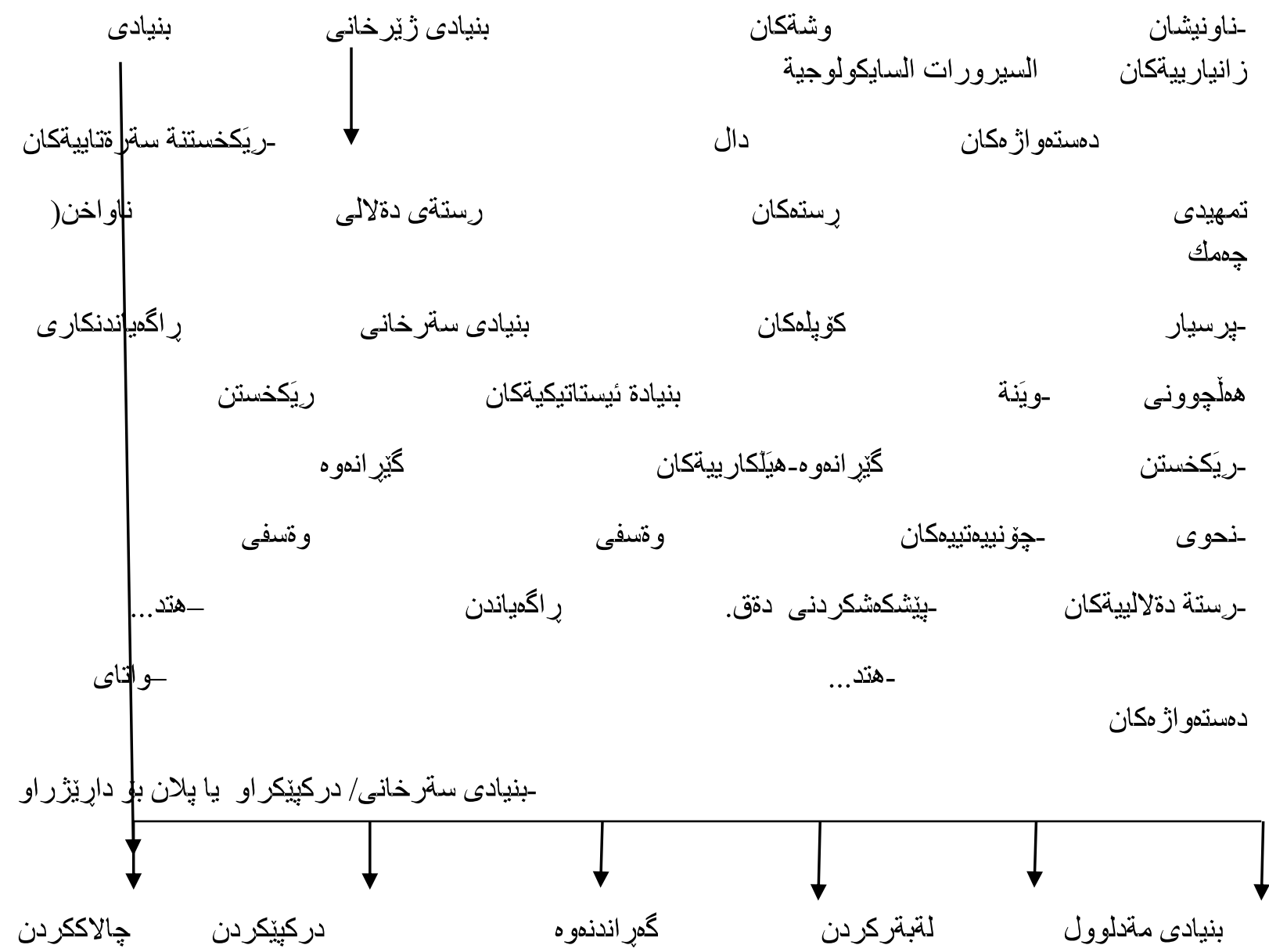

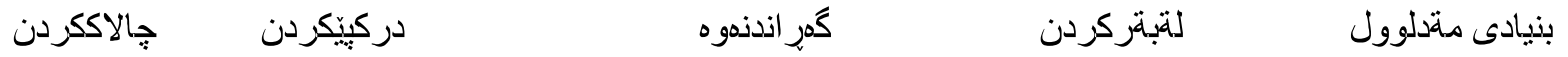

نمايش/ يا نيشاندان

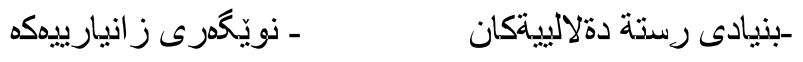

- كرينكى نسبى

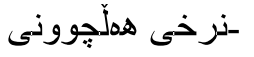

- - الاستدلال

شتةكان وسياق

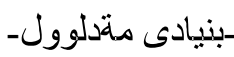

- دا هيَنان

كوّ يلِكان
-تيّكهيثتن له ز انيار ييهكانلة بيرةوةرى -نهختينهى زانيارييهكان -خهت/ذووسين

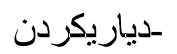

ـ هةتو تثناندنةوة

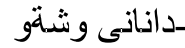

-عمل موضعى(وشةكان، الانتقاء

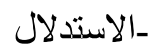

$$
\text { بمشى دووهم / 1-دهقى مهحكمم جيييه ؟ }
$$

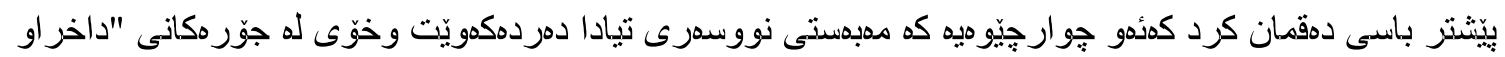

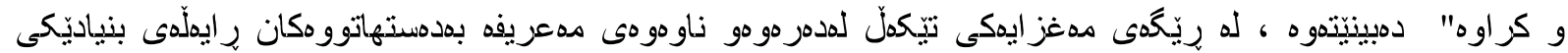

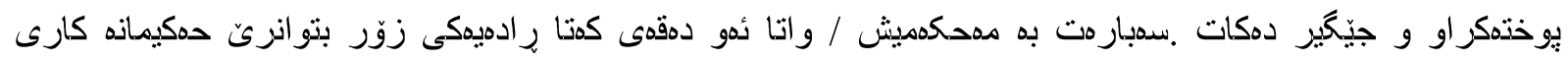




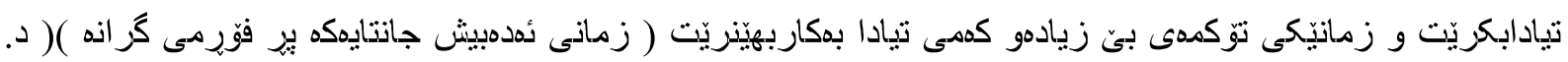

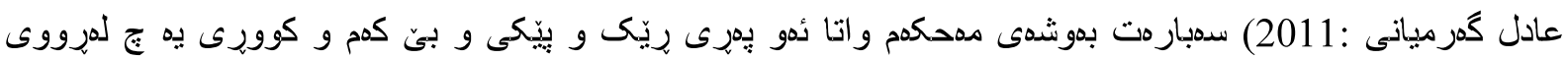

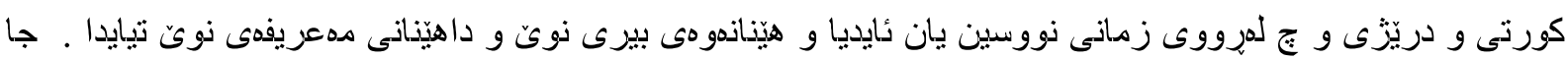

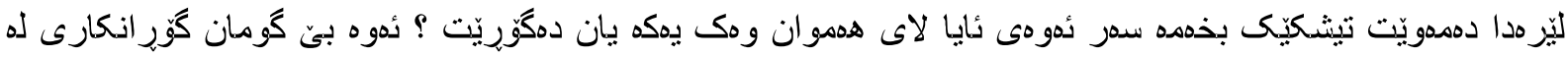

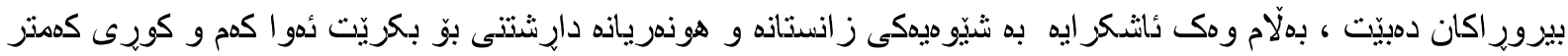
دمبيّت و مدحكمد دمبيّت .

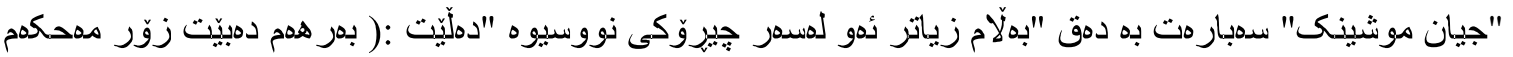

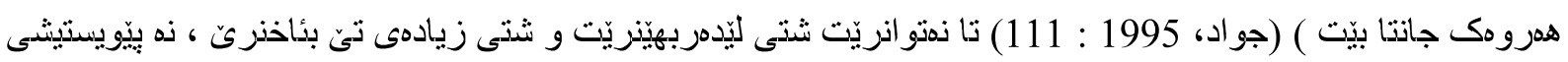

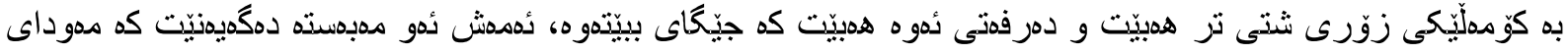

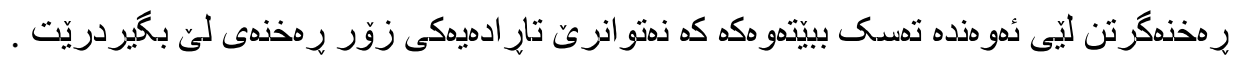

-2مدبهست له شيكردذهو مهى مهحمديانهى دمق جييه؟

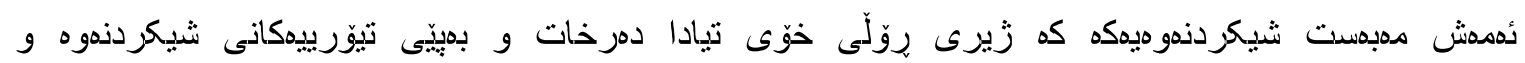

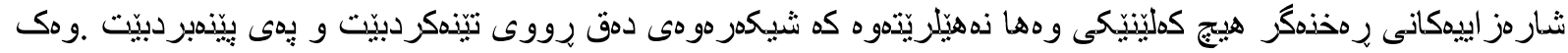

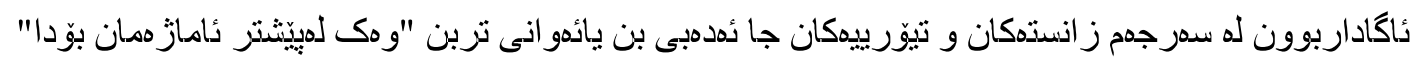
3 -بميو هندى مهحكمهيهت به بنيادكمرييهوه:

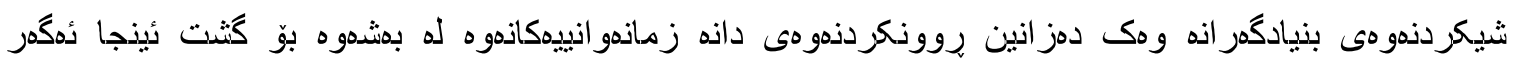

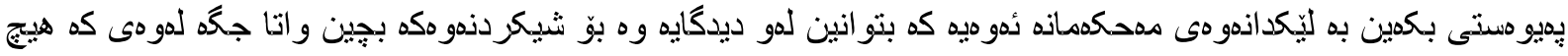

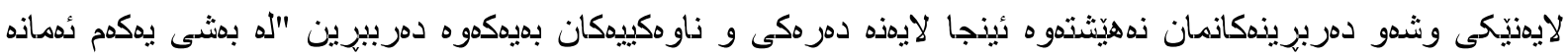

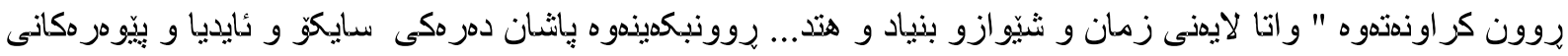

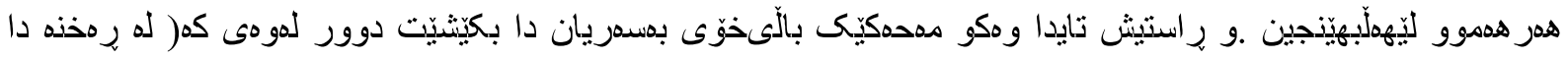

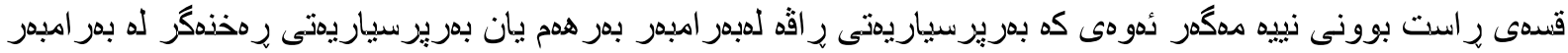

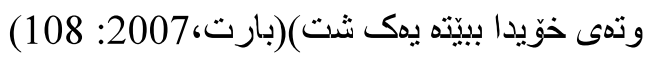

|-4 نموونهى شيكردنهو مهى مهكمهى دمقيّكى شيعزى: ئافر هتيّى به جزبِه وتى

له بيلبيلهى جاوى برينيّكى كونا

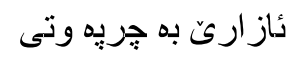$$
\text { من ئافر متم }
$$ 


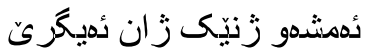

$$
\begin{aligned}
& \text { بمرى لدمنزم } \\
& \text { له ئاويّنهى نيخا شدكهت بوو دكميدا } \\
& \text { ويّنهى ئدو يِياوه ئهبينم } \\
& \text { كه لهباو هشى خهو دايه و } \\
& \text { تا بهيانى له جياتى ئهو }
\end{aligned}
$$

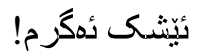

$$
\begin{aligned}
& * * * \\
& \text { لدهمثدو شدهو دلّدارييه } \\
& \text { من سديزى يَيّو هندهكانى } \\
& \text { دهستى دلّدار مكهم ئهكمم } \\
& \text { ئهويش سديزى دُهو فرميّدكه ويّلّه ئهكات } \\
& \text { كه به ذمزمى زير مى زنجيز هكمى قاجٍم دائدبارى } \\
& \text { ئدو ساتانهى سدما ئهكاو }
\end{aligned}
$$

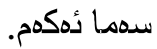

$$
\begin{aligned}
& \text { *** } \\
& \text { ئهمثدو شهوى بووكينيمه و } \\
& \text { جلى سييم لهبهر ئهكرى }
\end{aligned}
$$

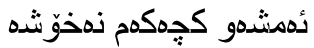

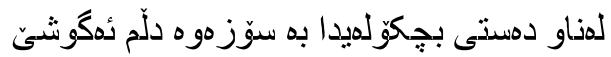

$$
\begin{aligned}
& \text { من نيشتيمانيّكى سدوزم } \\
& \text { لهو هتهى هوم بهسدر جو انيما هذلّئهدرى } \\
& \text { قدلّهمهكانتان بشكيَنن } \\
& \text { كمس و مكو خوّم } \\
& \text { ميّزووى بوونم تّومار ناكاو } \\
& \text { روّمانى خهمم ناذووسيّ } \\
& \text { *** } \\
& \text { ئهكمر هاتى }
\end{aligned}
$$

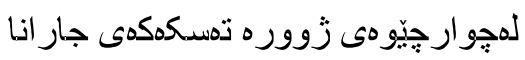

$$
\begin{aligned}
& \text { بوّم مدكمر عَّ } \\
& \text { ئيّستا هدورى نئاسمانيّكم } \\
& \text { عهثق و شيعزم لىّ ثٔدبارى } \\
& \text { *** } \\
& \text { به نيخايهك ليّم دُهيزسىى }
\end{aligned}
$$

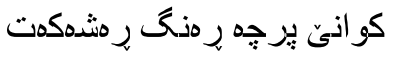




$$
\begin{aligned}
& \text { كمى هذلّونرى ؟!! }
\end{aligned}
$$

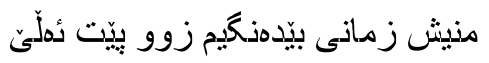

$$
\begin{aligned}
& \text { ئيّو ار ميهك فروَثتم و }
\end{aligned}
$$

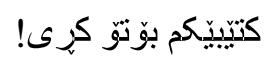

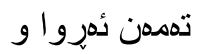

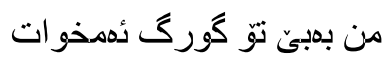

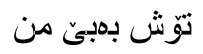

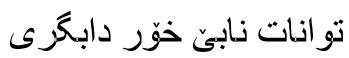

$$
\begin{aligned}
& \text { كيّز اوهكانى سدر زهمين لوولمان ئهدهن }
\end{aligned}
$$

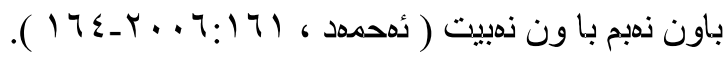

$$
\begin{aligned}
& \text { / 5ثيكردنهو }
\end{aligned}
$$

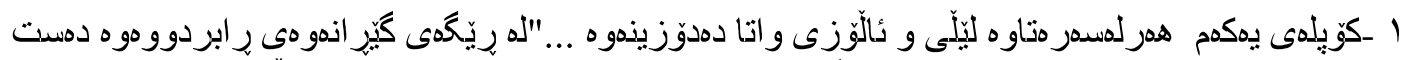

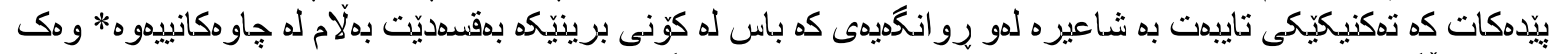

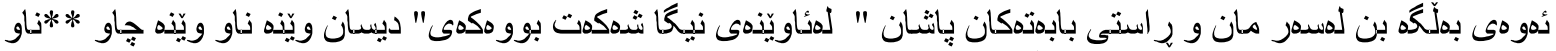

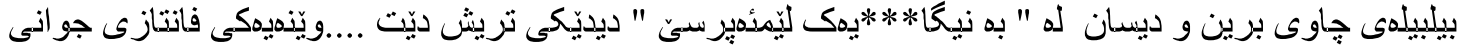

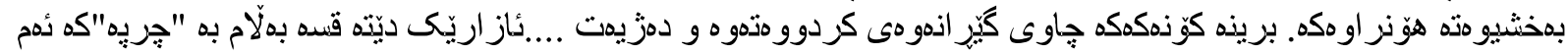

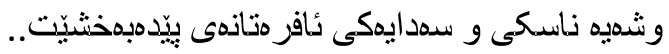

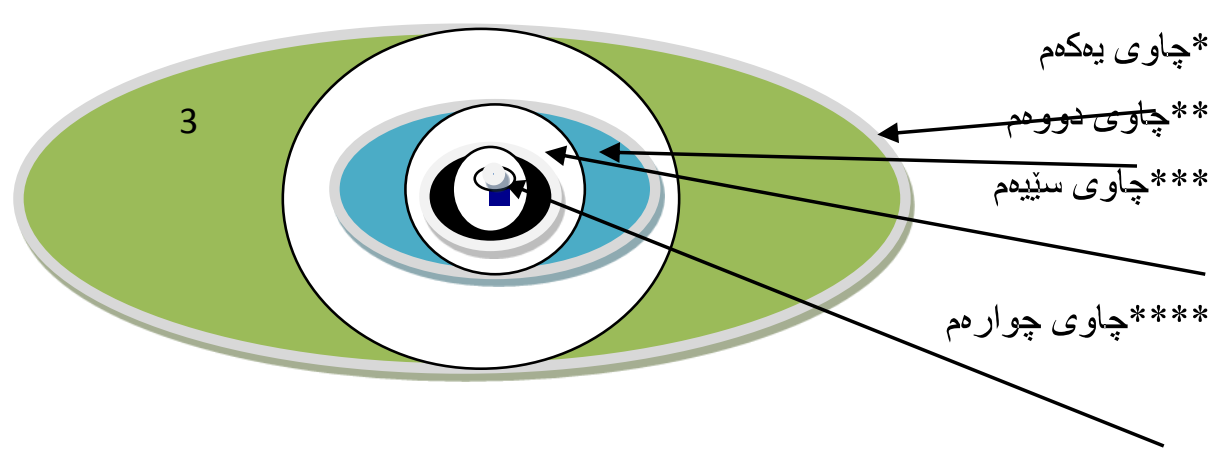

دز واتايى / يار ادوّكس : (بزيتييه له بديهكهوه هاتنى دوو وشه كه له بهكار هيّنانى هوَكاردا به شيّوهى دز يا 


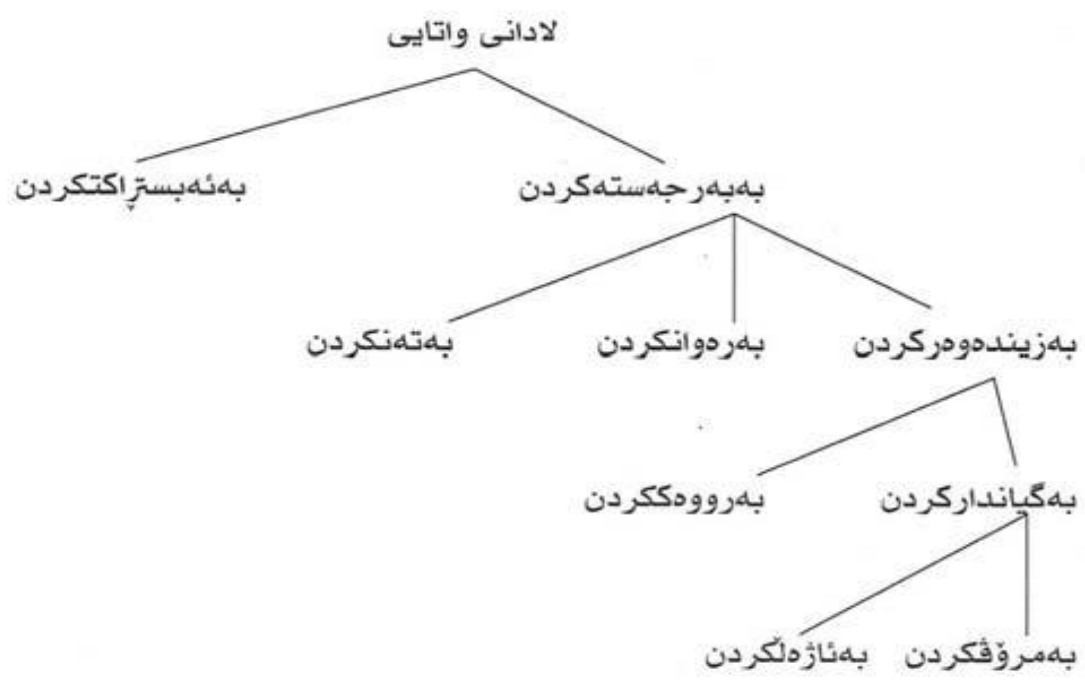

(كانبى ، 2009 : 209

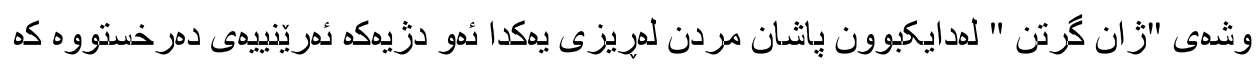

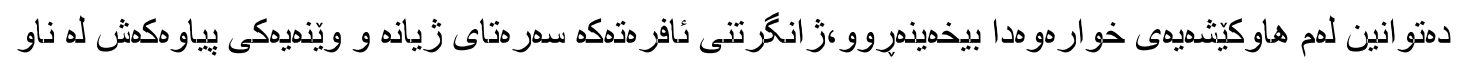

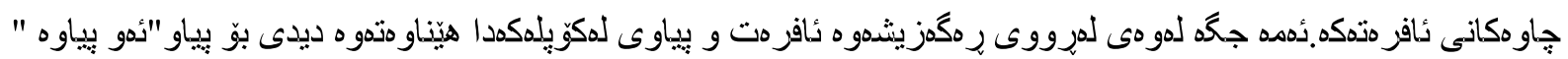

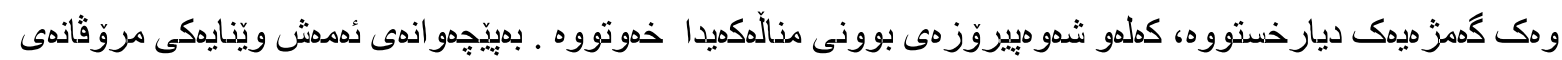

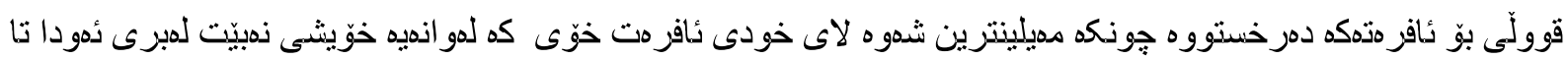
بديانى ناخهويّت.

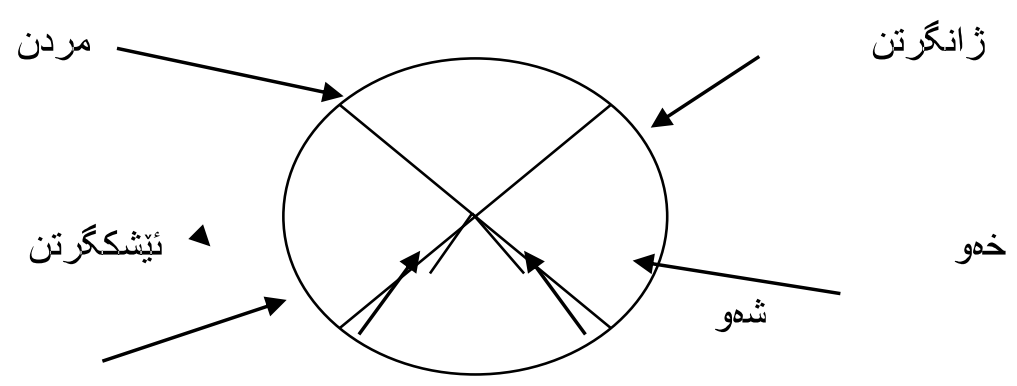

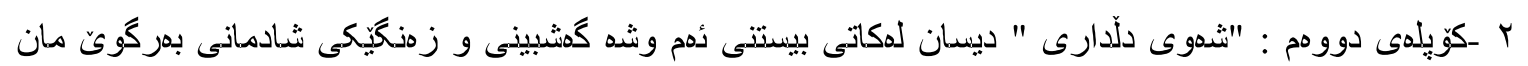

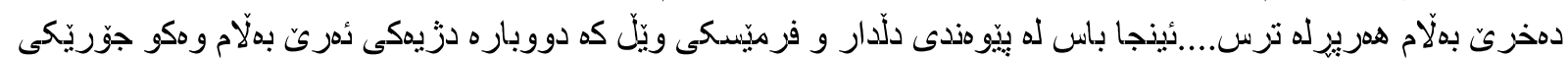

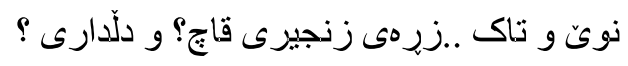

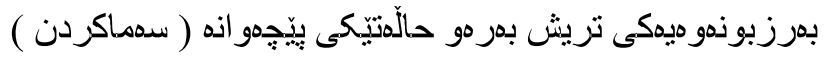

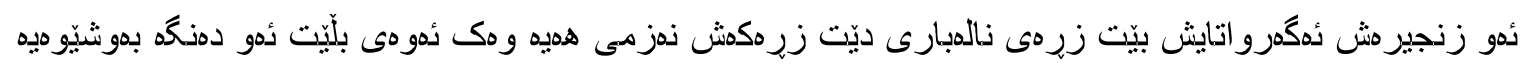
لاى ئدو بيستراوه.

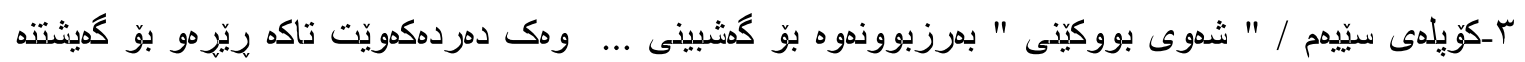

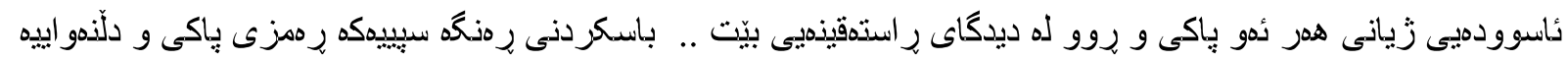

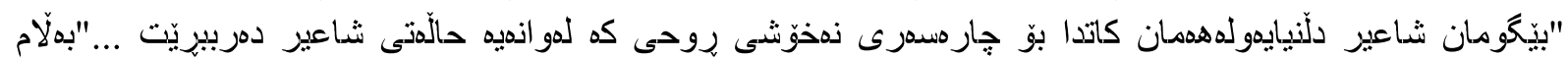

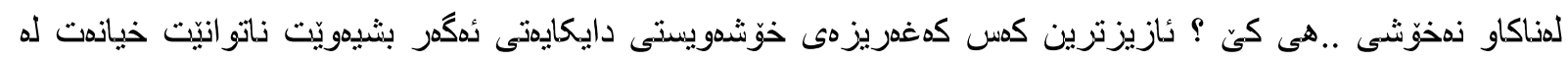

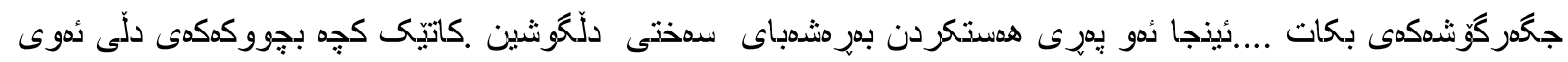




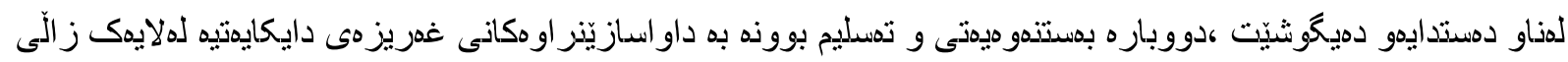

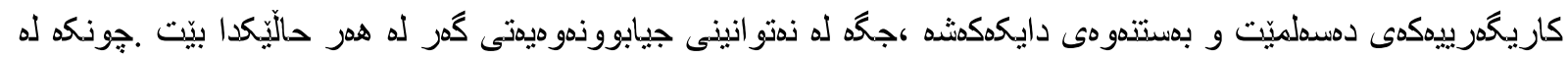

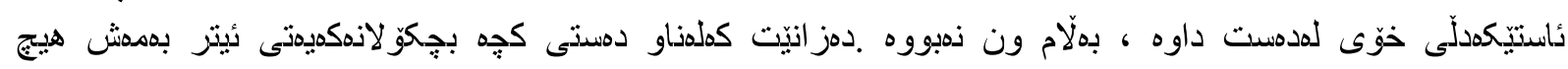

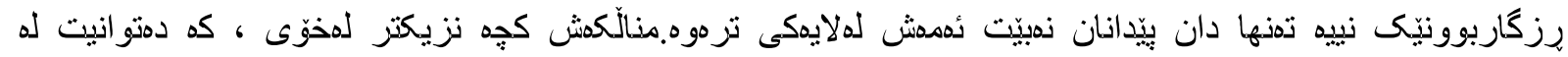

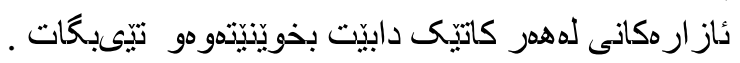

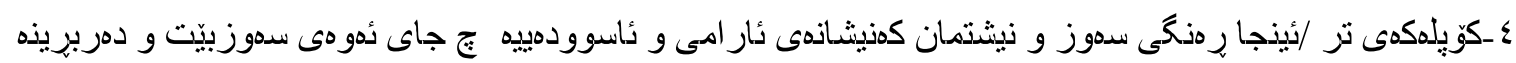

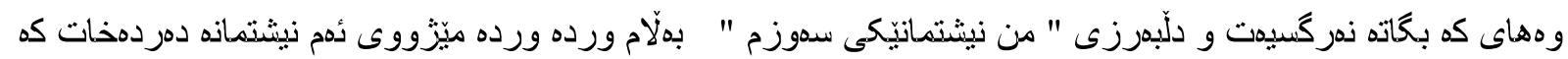

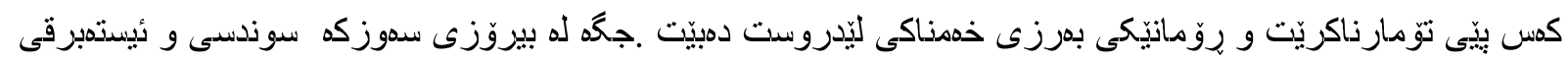
فير دموس ئدو ري منكمن .

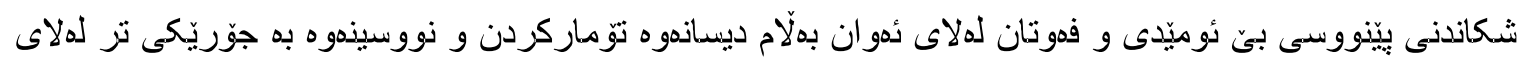

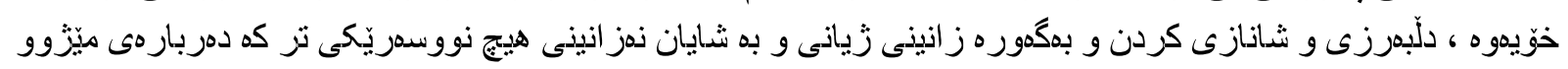

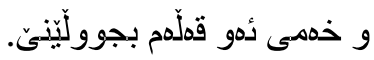

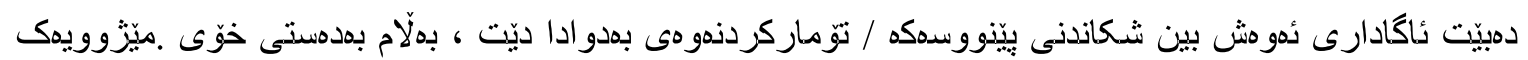

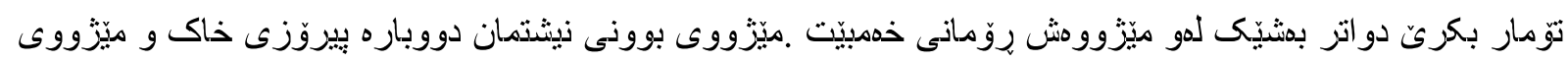

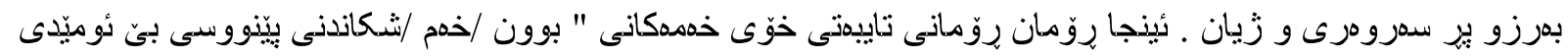

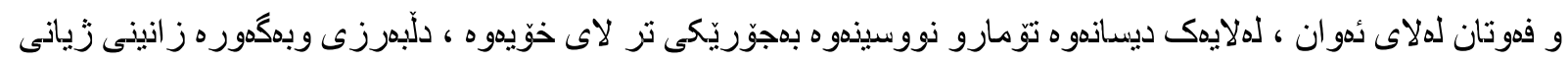

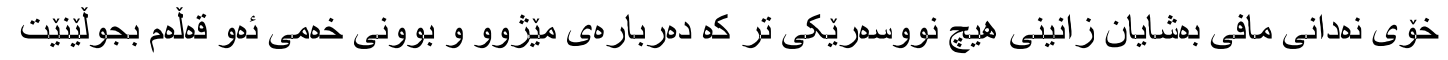

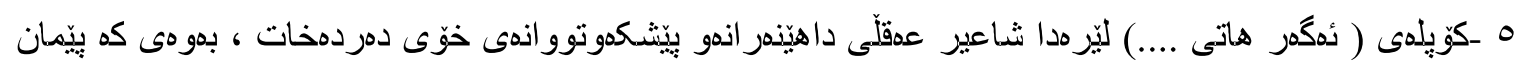

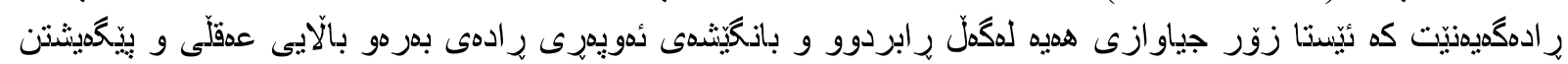

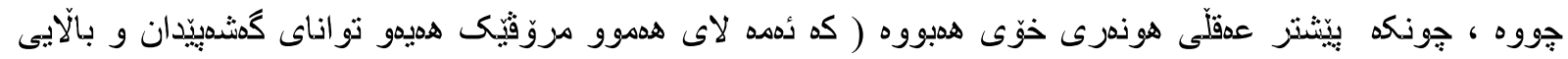

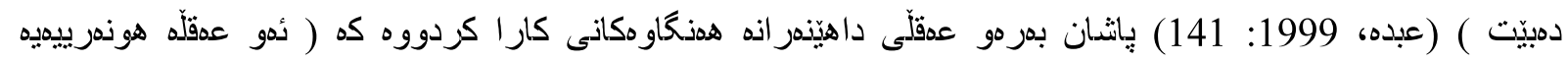

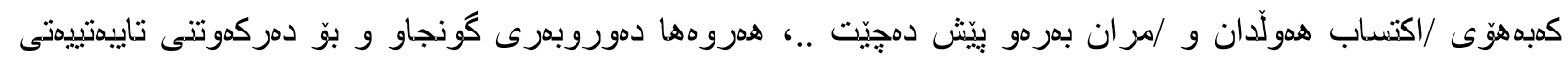

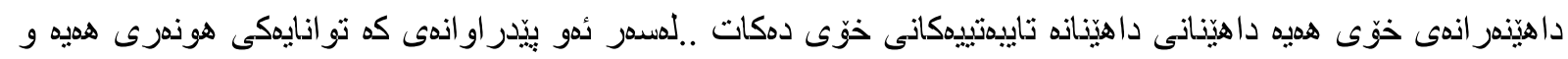

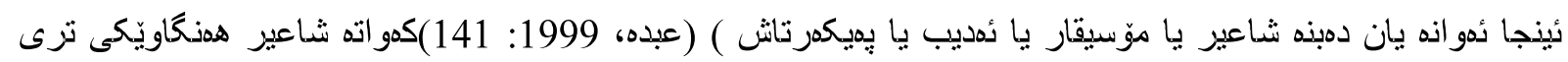

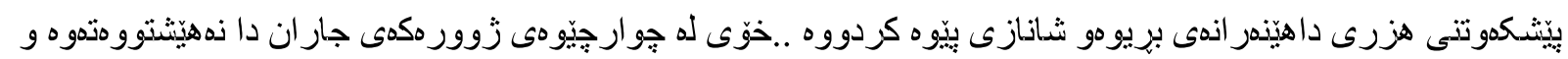

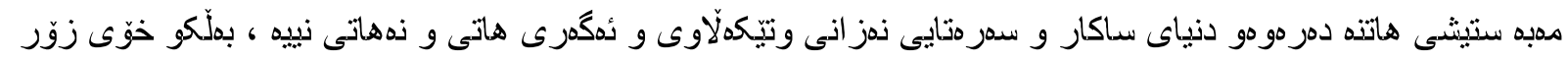

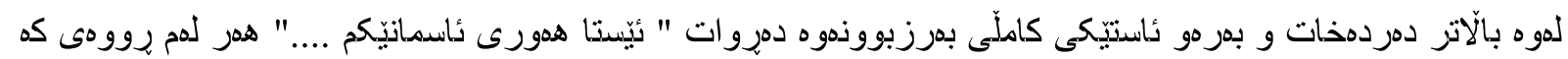

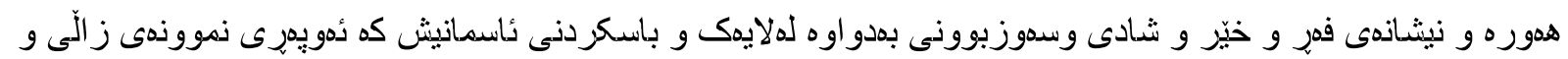

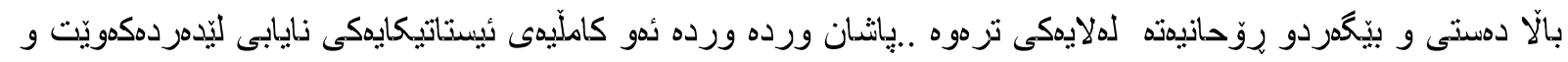

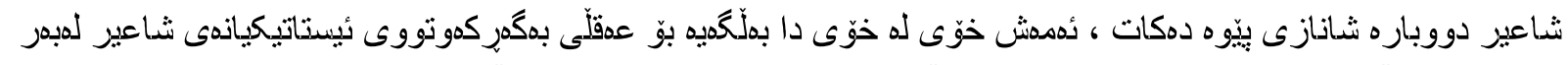

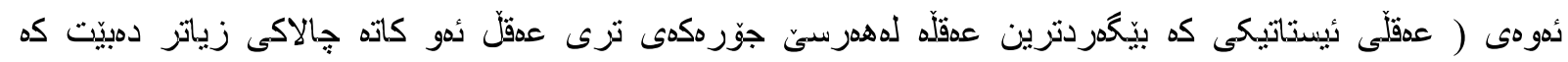

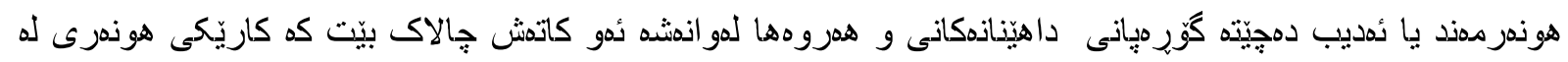

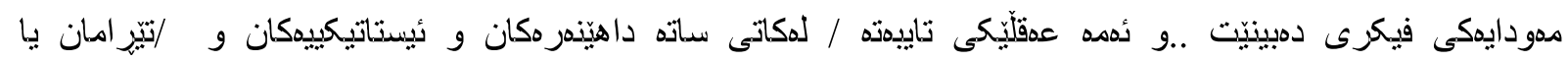

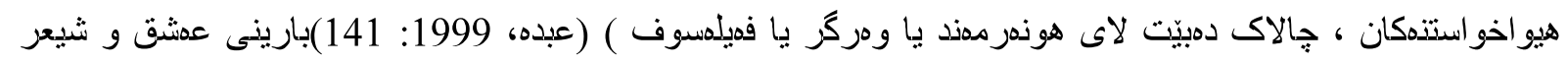

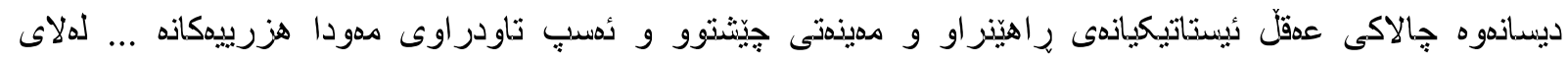

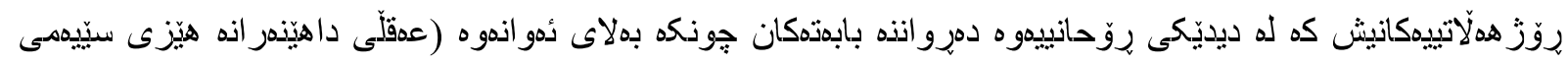

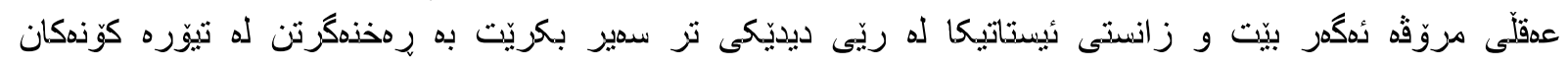

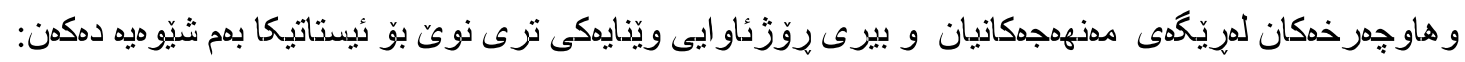




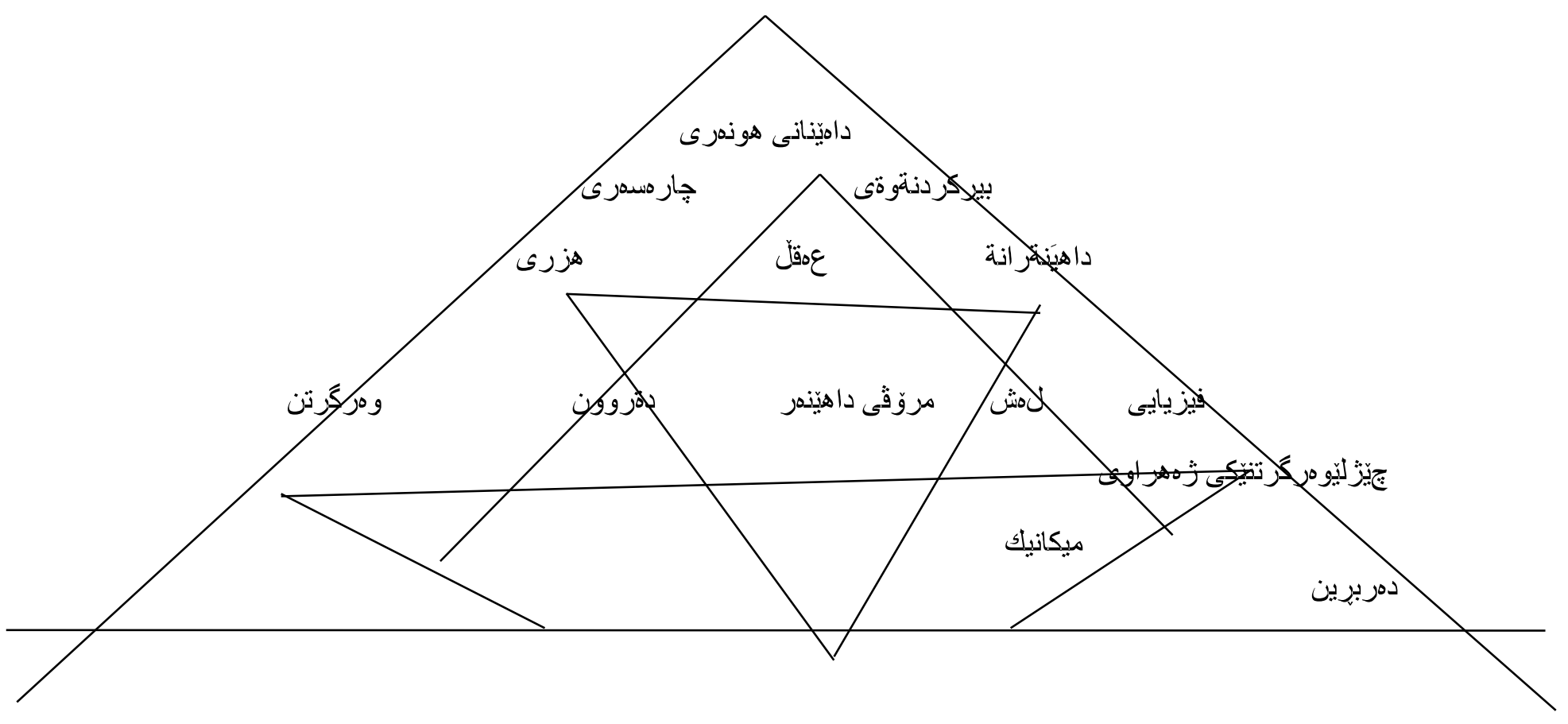

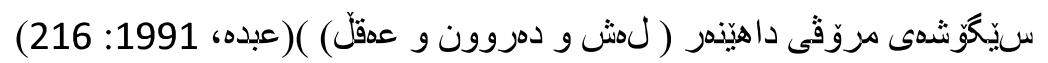

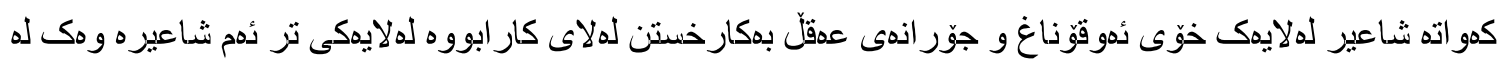

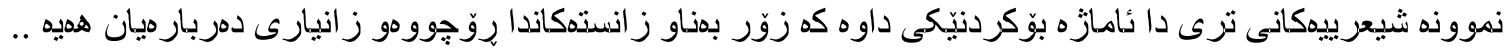

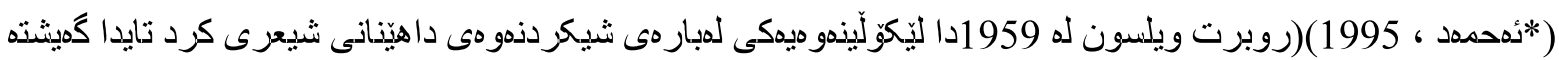

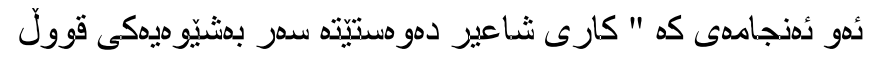

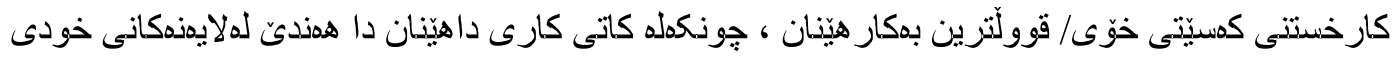
شاعير هكه به قوولّى دهدوزيتهوه كه ويّنهى نييه) (سويف ، 1998:

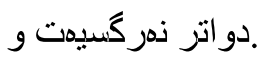

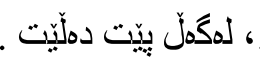

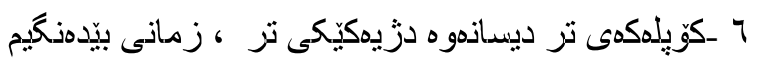

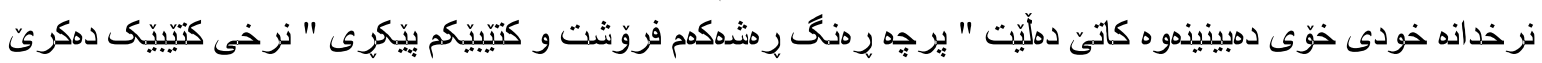

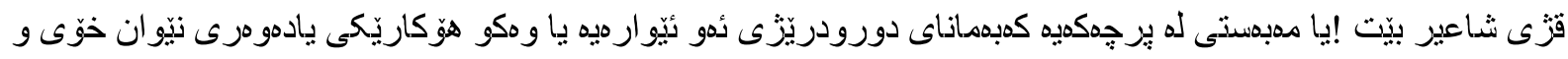

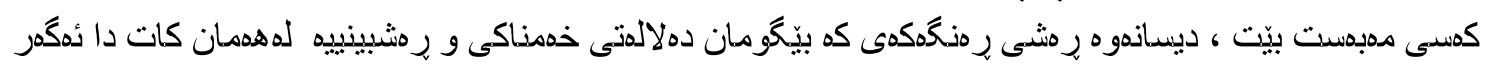

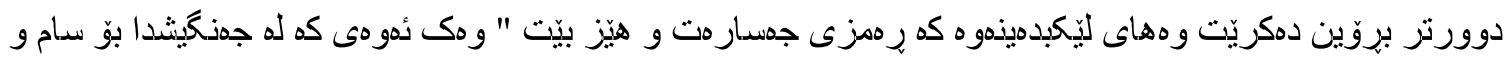

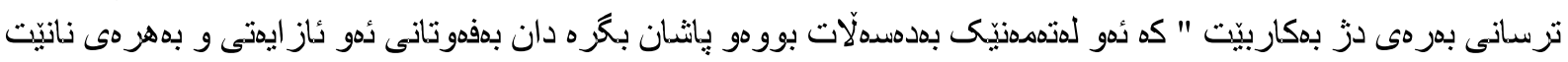

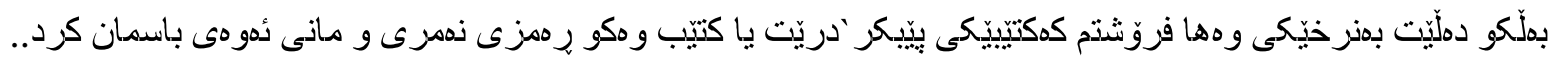

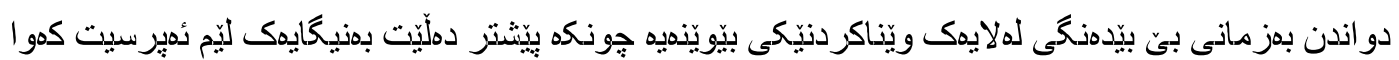

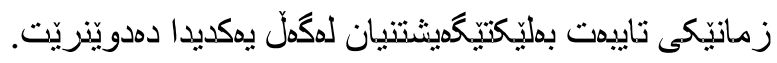

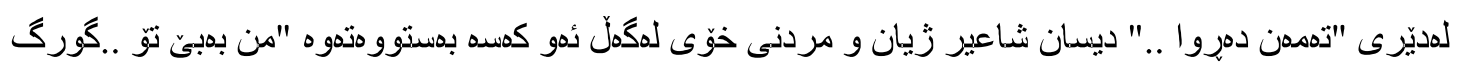

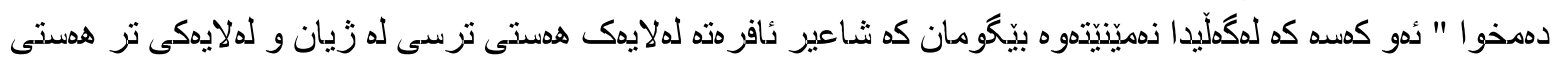

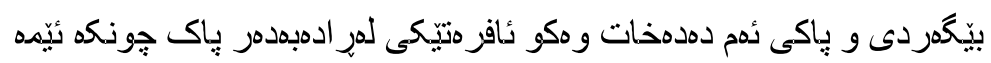

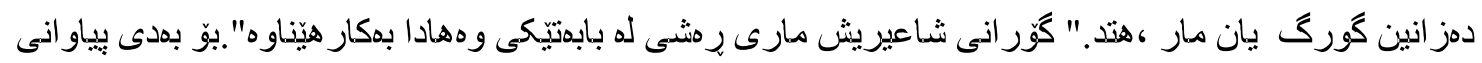

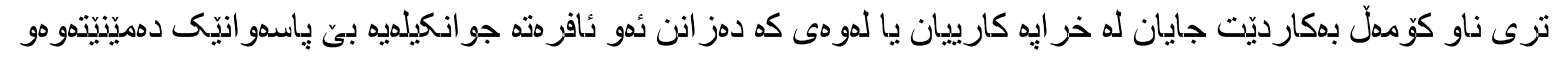

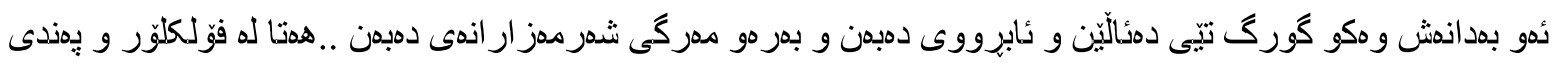

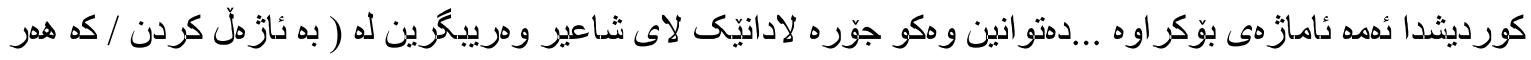




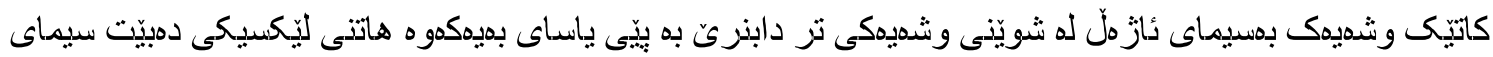

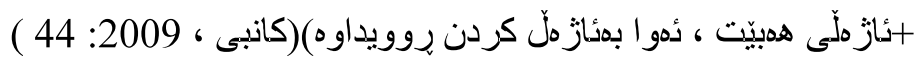

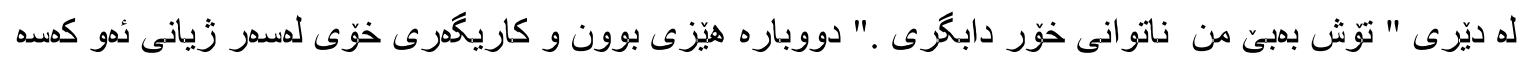

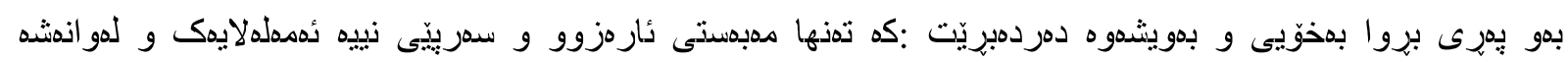

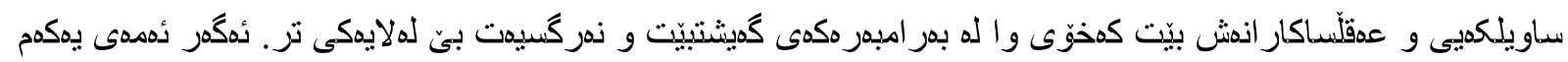

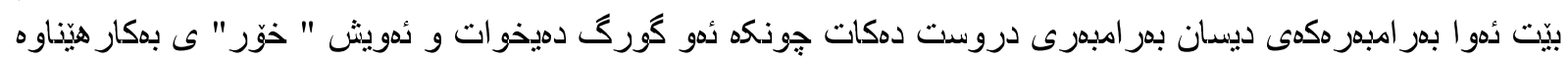

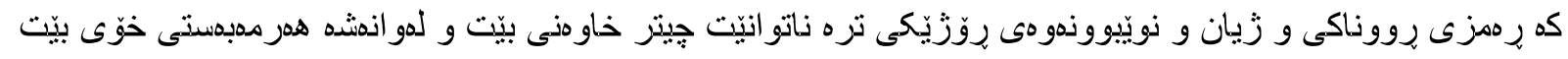

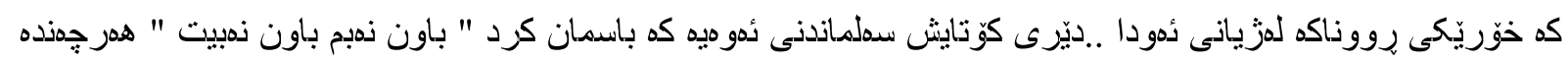

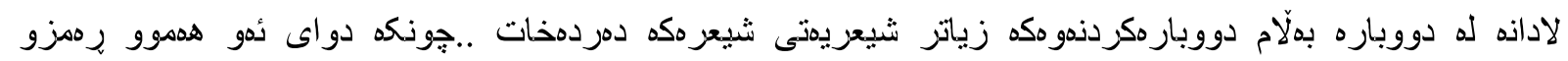

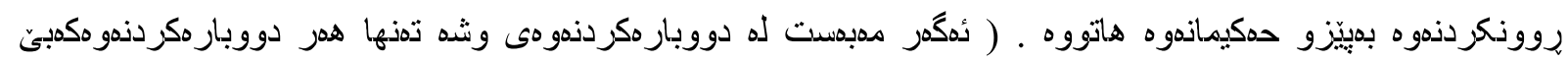

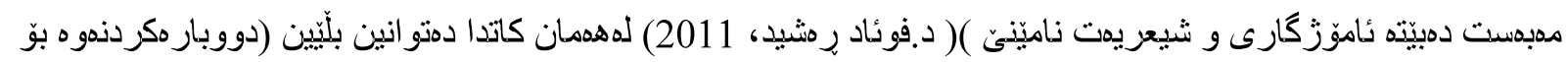

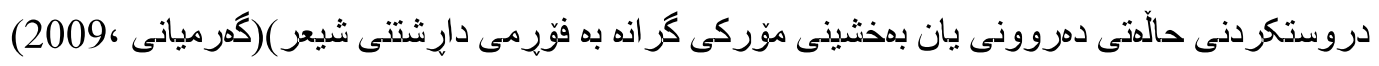

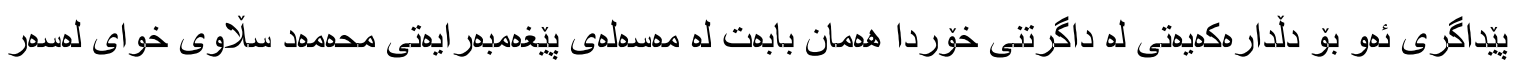

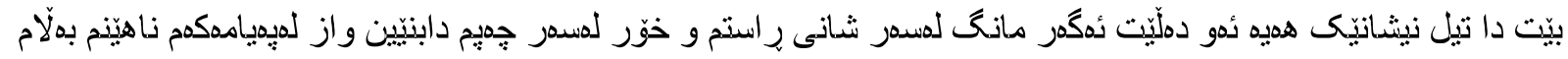

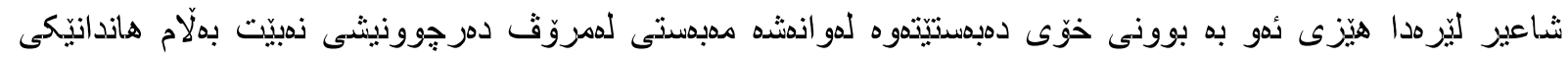

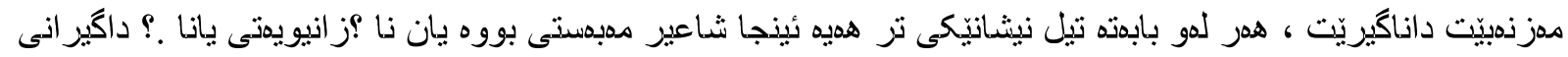

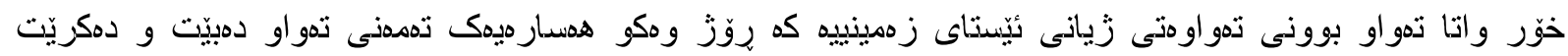
داكمويّتن.

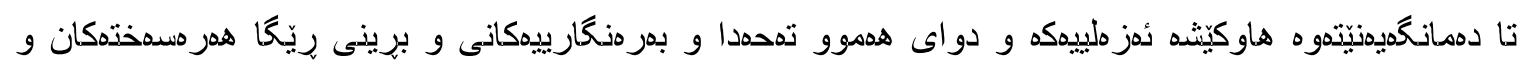

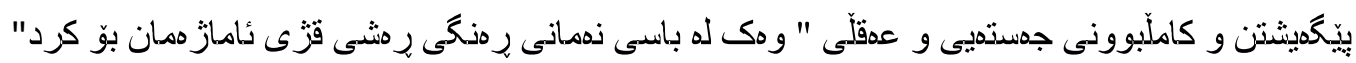

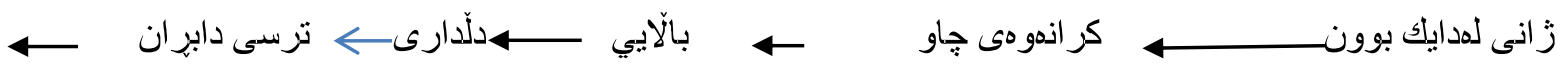

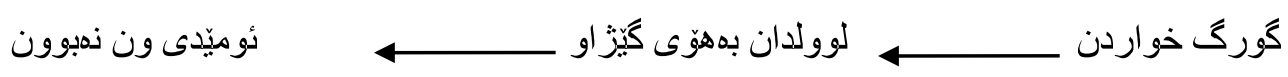

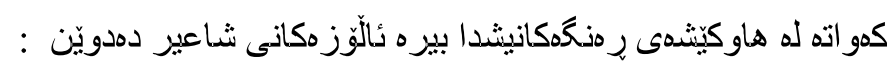
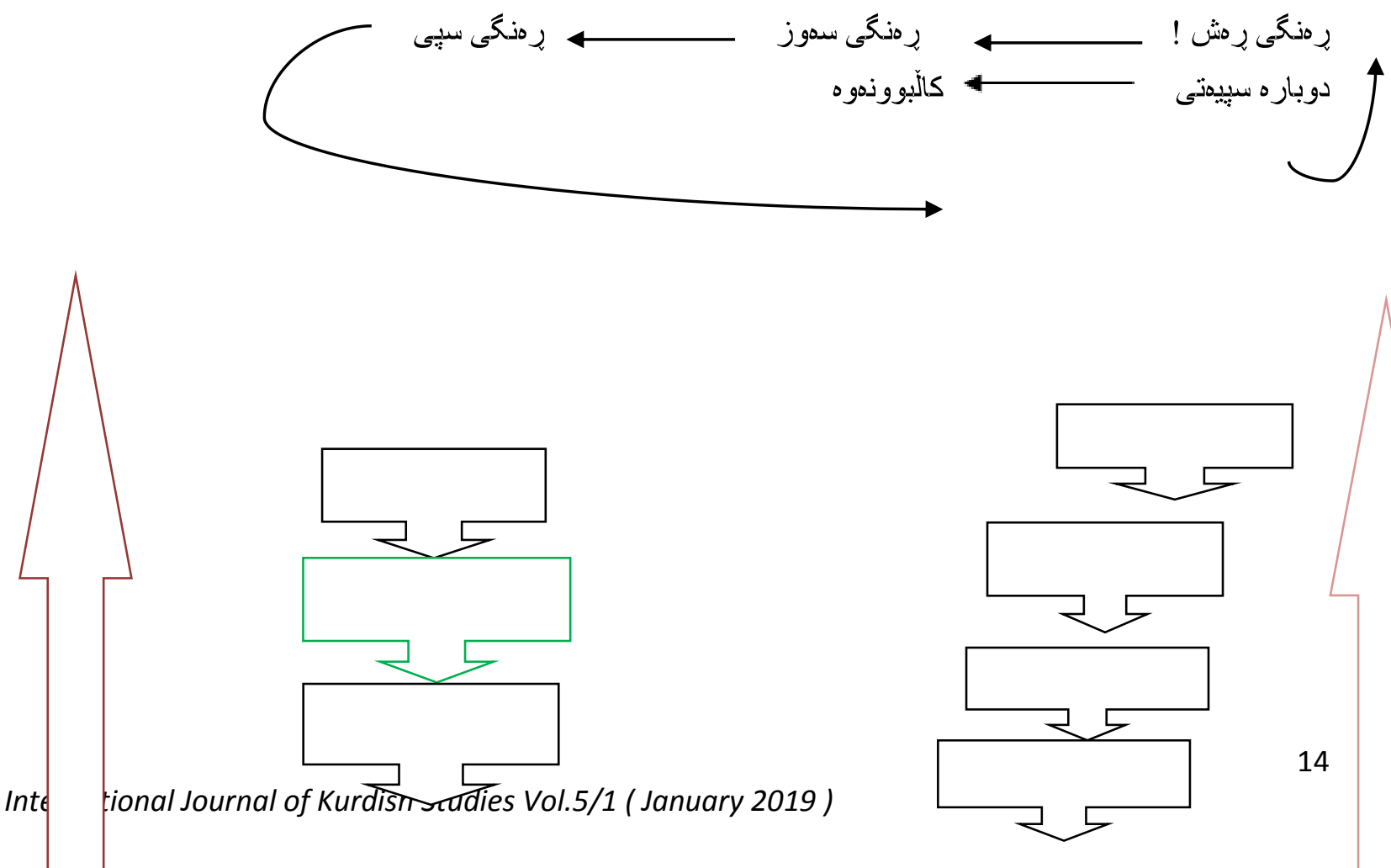


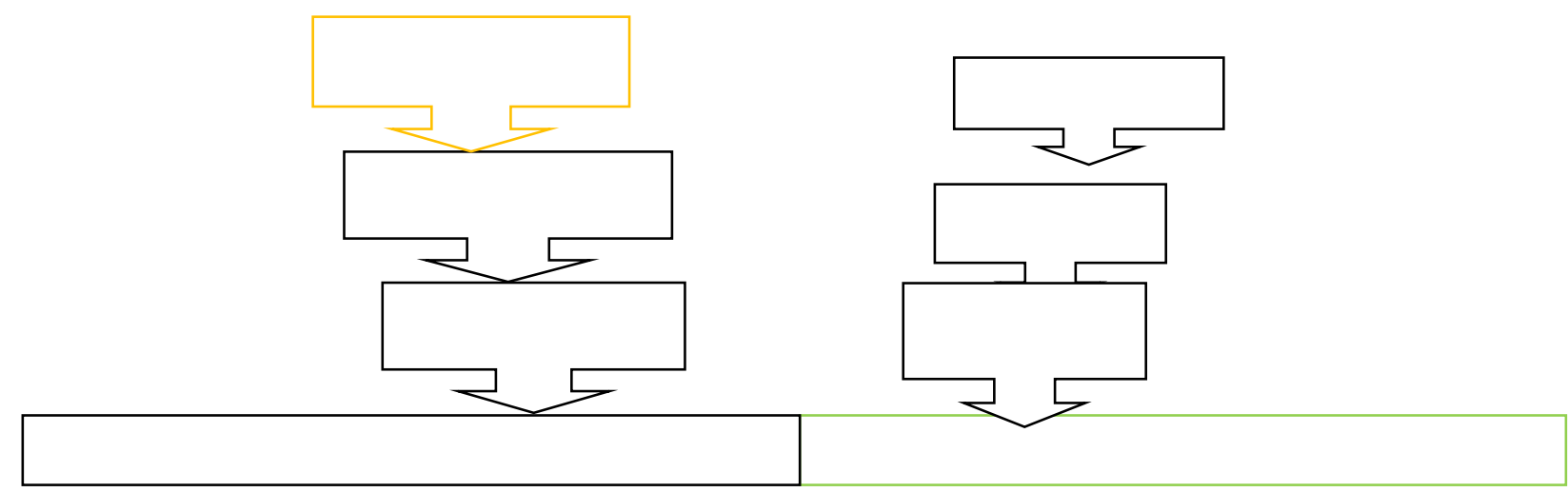

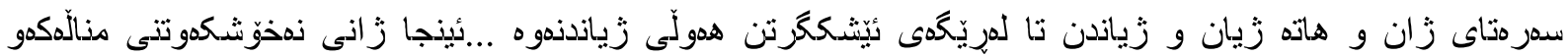

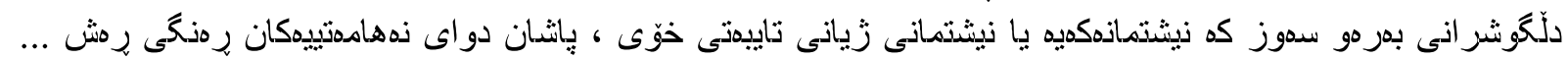

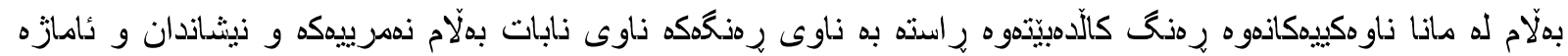

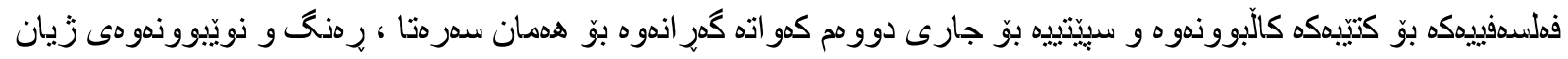

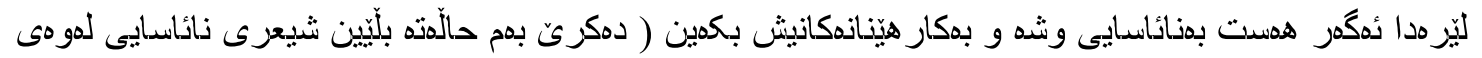

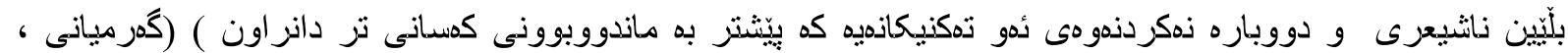

$$
\begin{aligned}
& \text { هدرسدبار مت بهلايدنى ناو هكيش. زمانى ( شيّورز ارى ناوجهيى ) بدديدهريّت :نمووذها }
\end{aligned}
$$

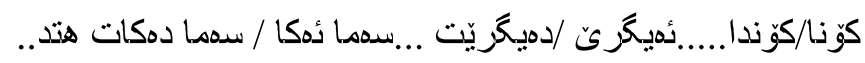

$$
\begin{aligned}
& \text {-رناوى كمسى سدربهخوّى من زوّرجار دووباره كر اوهتوه، ههروهها لكاويش /م. } \\
& \text { بميلهى دوو مميش نّو ئينجا ئدو.. }
\end{aligned}
$$

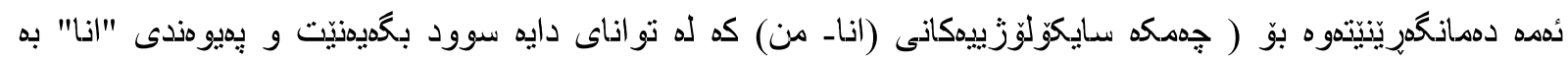

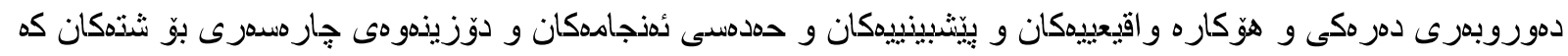

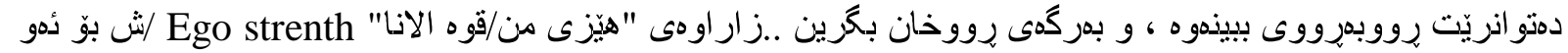

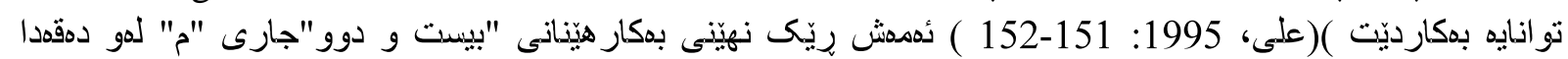

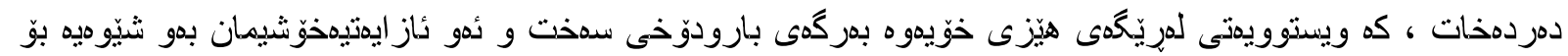

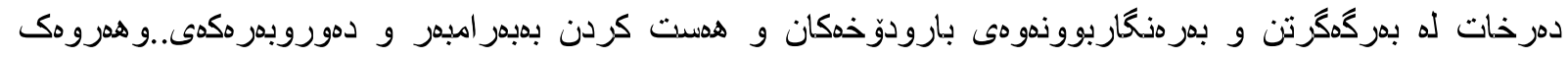

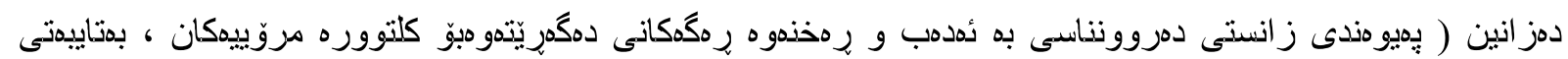

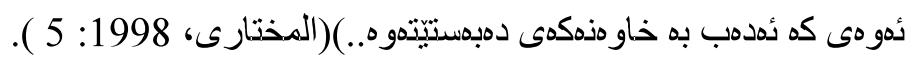

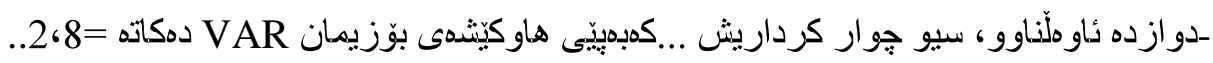

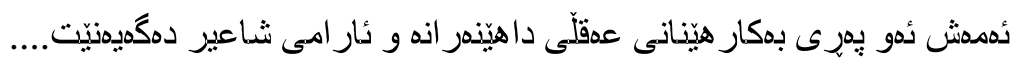

\section{ئدنجام}

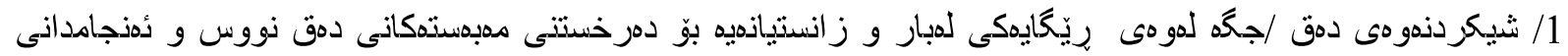

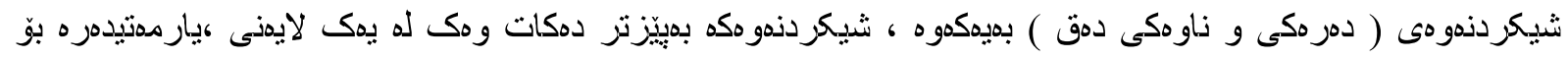




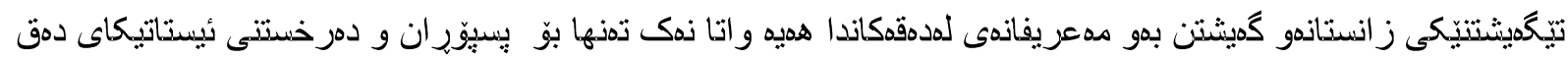

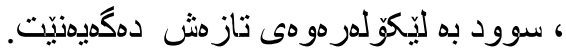

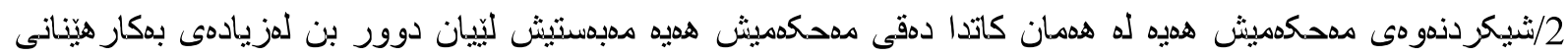

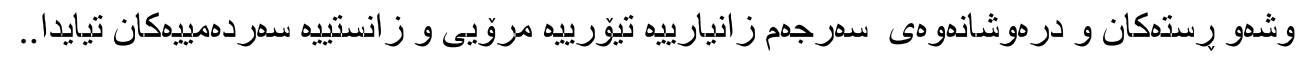

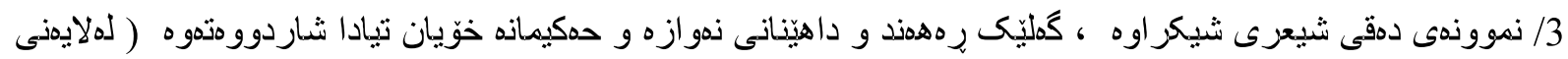

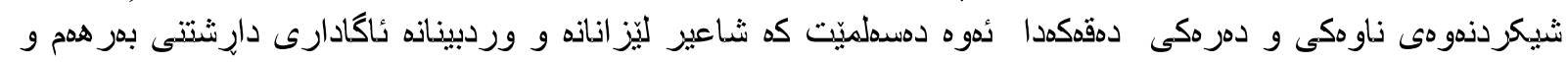
بابدتهكمى خوّى بووه ).

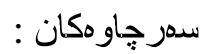
سدرجاو هان بززمانى كوردى:

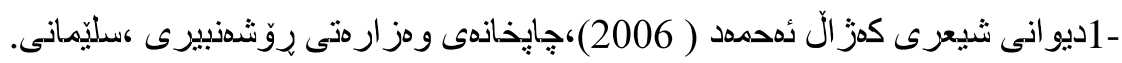

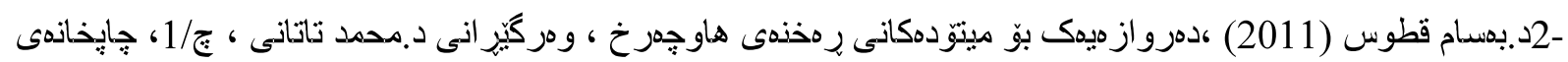

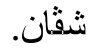

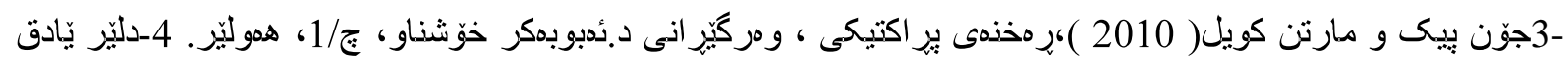

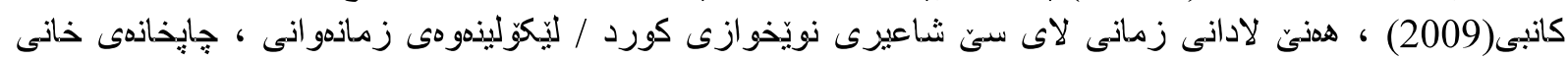

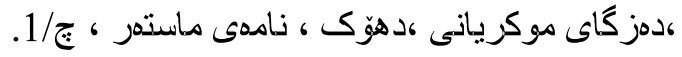
-5روّ لان بارت (2007)، رمخذهو حمقيقهت ، وهركيّر انى ئيسماعيل زر اعى ،ج/1،جإيخانهى مناره ، هووليّر .

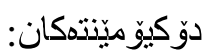
-1د. هيمدادى حسين (2012- 2013 )، محازهر مى ماستدر خويّندنى بالّا، ز انكوّى سدهلاحمدين.

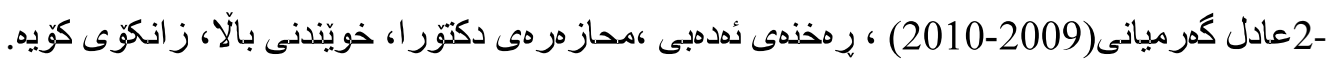

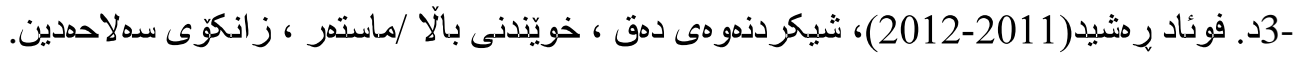

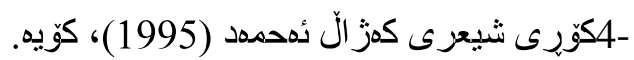

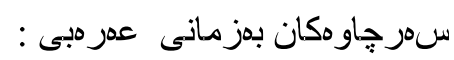
1-هندرى ويسينجز(2001)، قوة النقد البناء، عبد الكريم العقيل ؟هكتبة الجزيز ،ط/1. 2.د. احمد درويش(1996) ، فى النقدالتحليلى للقصيدة المعاصرة ، ط/1، دار الثروق ، القاهزة. 3-اندرية و جاك ديثين(1991) ،استعاب النصوص وتاليفهاكترجمة هيثم اللمع، ط/1، المؤسسة الجامعية لدر اساة النشر والتوزيع . 4-حاتم الصكر(1998)، تزويض النص /در اسة التحليل النصى فى النقد المعاصر ، الهيئة المصرية العامة للكتاب. 5-زين الدين المختارى(1998) ،المدخل الى نظرية النقد النفسى / در اسة ، منشور ات اتحاد كتاب العزب. 6- رولان بارت(1992)، لذة النص، ترجمة د.منذر العياش، ط1، سوريا.. 7-د. مصطفى سويف(1998) ، الاسس النفسية للابداع الفنى /فى الثعر خاصة ، ط/4، دار المعارف ، القاهزة. 


$$
\begin{aligned}
& \text { 8-مصطفى عبدة (1999)، فلسفة الجمال و دور العقل فى الابداع الفنى ، ط/2 ، مكتبة مدبولى ، القاهزة. } \\
& \text { 9-مصطفى عبدة(1991) ، مدخل الى فلسفة الجمال ، در اسات فلسفية ونقدية وتحليلية وتاصيلية ، ط/2، مكتبة مدبولى ، } \\
& \text { القاهزة. } \\
& \text { 10-محمد تحريشى (2000)، ادوات النص ، اتحاد كتاب العزب ، دمثق،مكتبة الاسد. } \\
& \text { 11- د. على اسماعيل على (1995)، نظرية التحليل الذفسى /واتجاهاتة الحديثة،دار المعرفة الجامعية ، الاسكندرية. } \\
& \text { 12-مجمو عة من المؤلفين (1995)، تقنيات كتابة القصة القصيرة و الزواية ، ت/ ر رعد عبد الجليل جواد ، دار الحزية للنشر } \\
& \text { و الطابعة ، ط/12، سوريا . } \\
& \text { 13-د. صبرى حافظ(1996) ، افق خطاب النقدى / در اسات نظرية و در اسات تطبيقية ، ط/1، دار الثرقيات للنشر } \\
& \text { والتوزيع ، القاهزة. } \\
& \text { wwww.al riyadh.com.( }
\end{aligned}
$$

\section{References}

\section{Sources in Kurdish:}

Ahmad, Kazaal, (2006). Ministry of Culture Press, Sulaymaniyah.

Bart, Roland, (2007). Criticism and truth, translation Ismail agricultural, printed 1, Manara Press, Erbil.

Kanabi, Delir Sadiq, (2009). Some linguistic aberrations in 3 contemporary Kurdish poets / linguistic research, Khani Press, Mukaryani Foundation, Dahak, MA, print / 1.

Qutus, Batsam, (2011). A door to contemporary monetary developments, the translation of Dr. Mohammed Tatani, printed / 1, Shvan Press.

The Thicken and Martin Coyle, (2010). Applied Criticism, Translation by Dr. Baker Khoashnau, Printed / 1, Erbil.

\section{The documents:}

Hussein, Hemedi, (2012-2013). Lectures Master, Higher Education, University of Salahaddin.

Khermiani, Adel, (2009-2010). Literary criticism, lectures Doctor, Higher Education, University of Kuyah.

Poetic seminar for the poet Kazal Ahmad (1995). Koya.

Rashid, Fuad, (2011-2012). Text Analysis, Master's Lectures, Higher Education, Salahaddin University.

\section{Published in Arabic:}

Abda, Mustafa, (1991). An introduction to the philosophy of beauty, philosophical studies, monetary and analytical and detailed, I -2, Madbouli Library, Cairo. 
Abda, Mustafa, (1999). Philosophy of beauty and the role of mind in artistic creativity 'I - 2, Madbouli Library, Cairo.

Al-Mukhtari, Zinedine, (1998). Introduction to the Theory of Psychological Criticism , Study, Publications of the Union of Arab Writers.

Al-Sukkar, Hatem, (1998). Timing the text, study of textual analysis in contemporary criticism, the Egyptian General Book Organization.

Ali, Ismail Ali, (1995). Theory of Psychological Analysis / Modern Trends, University of Alexandria, Alexandria.

Bart, Roland, (1992). The Pleasure of Text, translated by Dr. Mather Al Ayash, I -1, Syria.

Collection of Authors, (1995). Techniques of Short Story Writing and Novel, T. -Raad Abdul Jalil Jawad, Dar Alhahriya Publishing and Printer, I - 1, Syria.

Darwish, Ahmed, (1996). In the criticism of the contemporary poem, I - 1, Dar Shorouk, Cairo.

Deshin, Andriyya \& Jack, (1991). The processing of texts and their translation, translation of Haitham Al-Lama, i - 1, the university institution for the teaching of publishing and distribution.

Hafez, Sabri, (1996). Commentary of the Monetary Letter, Theoretical Studies and Applied Studies, I - 1, Dar Alsharqiyat Publishing and Distribution, Cairo.

Suef, Mustafa. (1998). Psychological Foundations of Artistic Creativity, in Special Poetry, I 4, Dar Al Ma'aref, Cairo.

Tahreishi, Muhammad, (2000). Text Tools, Arab Book Union, Damascus, Assad Library.

Wiesinger, Hendry, (2001). The Power of Construction Criticism, Abdul Karim Al-Aqeel?, Al-Jarir Bookshop, I, 1.

\section{Sources on the Internet:}

Mortada, Abdulmalek, problematic open and closed text (www.alriyadh.com). 